Pamiętnik Literacki 2017, 4, s. 15-39

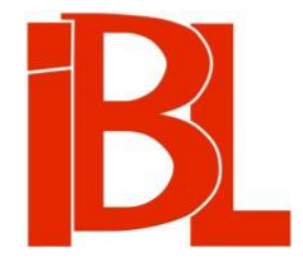

\title{
Zdzieranie i zakładanie masek. Stanisław Dygat i Witold Gombrowicz
}

Marian Bielecki 
Pamiętnik Literacki CVIII, 2017, z. 4, PL ISSN 0031-0514

DOI:10.18318/pl.2017.4.2

MARIAN BIELECKI Uniwersytet Wrocławski

\section{ZDZIERANIE I ZAKŁADANIE MASEK STANISŁAW DYGAT I WITOLD GOMBROWICZ}

Oszołomił mnie wtedy Gombrowicz $[\ldots]^{1}$.

\section{Piszac [Wspomnienie o Stefanie Otwinowskim], Stanisław Dygat przypomniał swo- ją relację $\mathrm{z}$ Witoldem Gombrowiczem:}

Nawet Gombrowicz lubił pójść ze mną na kolację do baru „Europejskiego” i szybko odkryłem, że w moim towarzystwie doznaje pewnego uczucia ulgi i relaksu. Jak powszechnie wiadomo, Gombrowicz lubował się w tak później nazwanym (chyba przez niego samego) dominowaniu otoczenia. Być może on sam czuł się tym czasem zmęczony. Ja byłem jedynym, którego nigdy nie próbował dominować. Dominować nieudanego tenisistę i pseudostudenta? To wręcz infantylizowało i odbierało całą dynamikę jego idei dominowania. Dlatego prowadziliśmy zupełnie normalne, wcale nie Gombrowiczowskie lub na pół Gombrowiczowskie rozmowy, bezkonfliktowe i rzeczowe, ja nigdy niczemu, co mówił, nie zaprzeczałem, a on mówił wiele prostych i mądrych prawd, których nie powiedziałby swoim współgraczom przy stoliku w „Zodiaku”, ze względów taktyczno-strategicznych, w wielkich bitwach Dominacji, które zawsze wygrywał, choć bardzo często niezasłużenie. [U-1 260-261] ${ }^{2}$

$1 \quad$ S. Dy g a t, [Wspomnienie o Stefanie Otwinowskim]. W: Utwory rozproszone. T. 1. Warszawa 1991 (dalej: U-1), s. 259. W artykule stosuję również skróty do innych utworów S. Dy g a ta: D = Disneyland. Wyd. 7. Warszawa 1981; J = Jezioro Bodeńskie. Wyd. 8. Warszawa 1981; K = Kołonotatnik. Wyd. 2. Warszawa 1984; KD = Karnawat. - Dworzec $w$ Monachium. Warszawa 1981; N = Na pięć minut przed zaśnięciem. - W cieniu Brooklynu. Warszawa 1983; P = Podróż. Wyd. 10. Warszawa 1981; Pż = Pożegnania. Wyd. 9. Warszawa 1981; U-2 = Utwory rozproszone. T. 2. Warszawa 1991; W = Wiosna i niedźwiedzie. - Rozmyślania przy goleniu. Warszawa 1985. Ponadto wprowadzam skrót DW $=$ T. D o s t oj e w s ki, Wspomnienia człowieka z lochu. W: Opowieści. Warszawa 1929 (przeł. M. Grabows ka). Liczby po skrótach oznaczają stronice. W przypadku Utworów rozproszonych liczba po łączniku sygnalizuje numer tomu, a następna - stronicę.

2 W jednym $\mathrm{z}$ felietonów zebranych w tomie Rozmyślania przy goleniu S. D y gat wspomina: „Artura Sandauera, który bodaj gardzi sportem, pragnę poinformować, że w 1932 roku udało się Gombrowiczowi wygrać ze mną mecz w tenisa, chociaż byłem wtedy dobrym graczem i miałem swoje lokalne sukcesy" (W 191). K. B r a n dy s (Miesiace. 1978-1979. Paryż 1981, s. 240) pamięta deklarację Dygata: „oświadczył, że uwielbia Gombrowicza i Hemingwaya”. W. Lu to sła w s k i (cyt. za: J. Si e d l e c ka, Jaśnie Panicz. Warszawa 1997, s. 295), nb. lękający się spotkać z Gombrowiczem, tak opowiadał o tej relacji:

„Szwagier ubóstwiał Gombrowicza, ubóstwiał o nim mówić, zawsze gdzieś go wtrącił. Na jednym ze swoich wieczorów autorskich powiedział na przykład, że i on, i Gombrowicz wywodzą się od Rabelaisa [!].

Znał zresztą Gombrowicza osobiście, zdą̇̇ył poznać go przed wojna jako młody student, w café "Zodiak", gdzie - jak zawsze potem mówił - uczył się literatury, przysłuchując się rozmowom przy stoliku Gombrowicza". 
Przytoczona opowieść może być postrzegana jako niezwykła - i to z paru przynajmniej powodów. Oto Dygat zachowuje się cokolwiek osobliwie, jeśli zważyć na to, że niewątpliwie zdaje sobie sprawę $z$ wpływu Gombrowicza, zarówno w wymiarze interpersonalnym, jak i literackim ${ }^{3}$. Mało kto z pisarzy znajdujacych inspirację u autora Ferdydurki tak układał, przynajmniej we wspomnieniach, swoja z nim relację. Na ogół podobnym retrospekcjom towarzyszył cały szereg zabiegów obronnych, które najlepiej omówił, oczywiście, Harold Bloom ${ }^{4}$. To rzecz pierwsza. Po drugie, szczególne w owym wspomnieniu jest to, że ten rodzaj specyficznej uległości, połączonej $z$ autokreowaniem się na życiowego nieudacznika („zaaprobowali w jakiś sposób mnie, który byłem niczym”, U-1 260), okazuje się bardzo charakterystyczny dla bodaj wszystkich powieściowych protagonistów stworzonych przez Dygata. Wprawdzie w epitafijnym wspomnieniu przyznaje się on głównie do terminowania u Otwinowskiego (,Jestem uczniem Stefana”, U-1 258), wpływ Gombrowicza był jednak tak samo intensywny:

Oszołomił mnie wtedy Gombrowicz, zmaltretował duchowo i doprowadził do stanu utraty błogiej równowagi wiary w ostateczną moc codzienności, jak Mefisto Fausta. [U-1 259]

Lekcja Gombrowicza była zatem doświadczeniem doniosłym, w jakiejś też mierze traumatycznym. Tak czy owak, deklaracje te dają asumpt do zestawień $z$ autorem Ferdydurki, który uchodzi za pisarza subwersywnego. Potencjalnych egzegetów skazuje to jednak na zapoznanie takich aspektów omawianej twórczości, które tę jego wywrotowość czyniłyby problematyczną. Oznaczałoby to podwójną

3 Również dla komentatorów ten literacki wpływ był oczywistością: J. I w a s z k i e w i c z, Jak oceniam literaturę Dwudziestolecia? „Twórczość” 1947, nr 4. - T. B r e z a, Niespodzianki Stanisława Dygata. „Odrodzenie” 1948, nr 7. - M. Piw ińs k a, Legenda romantyczna i szydercy. Warszawa 1973, s. 190. - Z. Skw a r z zý s ki, Stanisław Dygat. Warszawa 1976, s. 18, 54, 78-81, 137, 151. A. Sobolew ska, Polska proza psychologiczna (1945-1950). Warszawa 1979, s. 101. - E. Bis k u p, Sposoby czytania Dygata. „Ruch Literacki” 1983, z. 2. - R. K. Przy by ls ki, Autor i jego sobowtór. Wrocław 1988, s. 121-122, 127, 128. - J. To m k ow s k i, Wawel i Vence. Witold Gombrowicz. W zb.: Sporne postaci polskiej literatury współczesnej. Red. A. Brodzka. Warszawa 1994, s. 97. - B. G u t k o w s k a, Powieści Stanisława Dygata. Czas i przestrzeń życia i marzenia. Katowice 1996, s. 8, 24, 34, 36, 45, 84, 117, 121, 133, 135, 150. - J. J a rzę b s ki: Literatura polska pod znakiem Gombrowicza. W zb.: Lektury polonistyczne. Literatura współczesna. T. 1. Red. R. Ny c z, J. J a r z ę b s ki. Kraków 1997, s. 237-252; Lekcja literatury z Jerzym Jarzębskim i Andrzejem Zawadzkim. W: W. G o m b r ow i c z, Ferdydurke. Kraków 1997, s. 270-271; Pożegnanie z emigracja. O powojennej prozie polskiej. Kraków 1998, s. 133-134; Podgladanie Gombrowicza. Kraków 2001, s. 12. - G. He rling - Gru dziń s ki, Proza czasu wojny (1947). W: Wyjścia z milczenia. Szkice. Warszawa 1998, s. 126-127, 150. - M. J a n u s z k i e w i c z: Tropami egzystencjalizmu $w$ literaturze polskiej XX wieku. O prozie Aleksandra Wata, Stanisława Dygata i Edwarda Stachury. Poznań 1998, s. 110, 118, 121, 126, 138, 153, 176; Stanisław Dygat. Poznań 1999, s. 7-9, 17, 20-23, 26, 28, 49, 83, 102-103. - A. H o r u b a ł a, Sztafeta szyderców, czyli lustrowanie Gombrowicza. W: Marzenie o chuliganie. Warszawa 1999, s. 10-13, 31. - B. Si e n ki e wi c z, Nuda i świadomość $w$ powieści inteligenckiej. W zb.: Nuda w kulturze. Red. P. Czapliński, P. Śliwińs ki. Poznań 1999, s. 163-166. - K. Mojs a k, Groteska w polskiej prozie narracyjnej 1945-1968. Warszawa 2014, s. 132-134, 165-166.

4 H. Bloo m: A Map of Misreading. New York 1980; Lęk przed wpływem. Teoria poezji. Przeł. A. Bielik-Robson, M. Szu ster. Kraków 2002. Kategorie amerykańskiego teoretyka do opisu wpływu Gombrowicza zastosowałem w książce Historia, dialog, literatura. Interakcyjna teoria procesu historycznoliterackiego (Wrocław 2010). 
niewierność - wobec tekstu i wobec samego Dygata. Na marginesach podróży do Włoch wyznawał on, wspominając dość złośliwie Jeana-Jacques’a Rousseau:

Nie lubię obalać ani podważać ustalonych wielkości i bardzo boleję, gdy walą się mity, gdy fikcją i złudzeniem okazują się fragmenty owego powszechnego obrazu świata, który od narodzin począł się utrwalać w mej świadomości. [N 353]

Passus ów, tak jak cały fragment o autorze Przechadzek samotnego marzyciela, jest, oczywiście, ironiczny. Jest taki tym bardziej, że Dygat w powszechnej świadomości funkcjonuje jako demaskator mitów ${ }^{5}$. Ja myślę inaczej i w moim odczuciu ta jego ironiczna subwersywność nie zawsze zachowuje swoją moc, i to nawet w kontekście jego utworów w najwyższym stopniu demaskatorskich.

Na koniec niniejszego wstępu trzeba zauważyć również to, że inspiracja gombrowiczowska ogranicza się właściwie tylko do Jeziora Bodeńskiego. Poszczególne wątki i kwestie, które się na tę zależność składają, wprawdzie będą się pojawiały w późniejszych powieściach, ale można odnieść wrażenie, iż stopniowo traca znaczenie. Zainteresowanie tym, co w gombrowiczologii nazywa się problematyką interakcyjną, niby trwa, jednak Dygat staje się bardziej realistą nie tylko w wymiarze obyczajowym, lecz i historycznym oraz społeczno-politycznym. Zaczyna ujmować psychologię mimetycznie, a nie modelowo, nie inscenizuje eksperymentalnych sytuacji eksponujacych reguły gier interpersonalnych i funkcjonowanie konwencji społecznych, jak wtedy, gdy inspirował się tekstami antenata. Jakby nie interesowały go już próby uogólnień obyczajowych, socjologicznych czy antropologicznych na temat procesów kształtowania podmiotowości, czyli - co ciekawe - tego, co nie pozwala, zdaniem niektórych komentatorek, wpisywać prozy Dygata w kontekst „rozrachunków inteligenckich”, a więc powieści przedstawiających problematyczną sytuację inteligenta zmuszonego do odnalezienia się w zmienionych okolicznościach ustrojowych i w rewizji ideowego dziedzictwa Dwudziestolecia międzywojennego ${ }^{6}$. Tak jak bohater Jeziora Bodeńskiego miał być oderwany od doraźności historycznej (co deklarował autor w przedmowie do drugiego wydania), tak też jego następcy $\mathrm{z}$ kolejnych powieści będą mocno wplątani w konkret uwikłań rodzinnych i ustrojowych. Utwory te w większej mierze mają stanowić diagnozy swojego czasu i w takim sensie dopiero one wpisywałyby się w kontekst „rozrachunków inteligenckich” i rozliczeń z przeszłością: Dwudziestolecia i wojny, oraz teraźniejszością społeczno-polityczną. Ponadto wpływ Gombrowicza zdaje się nie obejmować opowiadań i felietonów, niezależnie nawet od daty ich powstawania. Osobliwe jest bowiem to, że teksty pisane omal równolegle $z$ najbardziej „gombrowiczowskim” utworem, Jeziorem Bodeńskim, nie przynosza potwierdzenia inspiracji.

$\mathrm{W}$ felietonach $\mathrm{z}$ tomu Wiosna i niedźwiedzie znajduje się sporo mniej lub bar-

5 Bohater autobiograficznego Pacific Panam Palisades przyznaje: „gdzie indziej staram się przedstawiać siebie jako jednostkę niezależną i usposobioną co najmniej opornie wobec ustalonych konwencji, osobę starającą się demaskować źródła ich fałszu oraz powszechną hipokryzję zawieranych układów [...]" (U-2 276).

$6 \quad$ Zob. S ob olews ka, op. cit., s. 37, 99. Zob. też H. Zaw or s k a, Po upadku mitów inteligenckich. O prozie tzw. obrachunków inteligenckich w latach 1945-1948. W zb.: Z problemów literatury polskiej XX wieku. T. 3: Literatura Polski Ludowej. Red. A. Brodzka, Z. Ża bi cki. Warszawa 1965. K. Wy ka, Rozrachunki inteligenckie. W: Pogranicze powieści. Wyd. 3. Warszawa 1989. 
dziej dowcipnej satyry i kiepskiej moralistyki, skierowanej przeciwko rozmaitym patologiom życia społeczno-kulturalnego. Mimo lekkiej ironii wymierzonej w programowy zapał (On i ona), nepotyzm (Piękna sztuka podlizywania się, Piękna sztuka popierania się), koniunkturalizm, oportunizm (O czym marzy Bezzarzutniak) i instytucjonalny formalizm (Nudziarze), mimo mniej czy bardziej udanych pastiszów oraz parodii nowomowy, żargonu produkcyjnego i materializmu dialektycznego teksty te maja co nieco wspólnego $\mathrm{z}$ socrealizmem. W omawianym tomie sa też utwory wycelowane we wrogi ideologicznie i aksjologicznie Zachód (Feliks Makuła, Co chciat przemycić Leslie Morris). Zbiór felietonów Rozmyślania przy goleniu to ciagg dalszy piętnowania zaniechań i nadużyć w sferze kultury.

Wspomniane moralizujące zacięcie dochodzi do głosu i w opowiadaniach, które prezentuja rozmaite poziomy i te samą, socrealistyczno-antysocrealistyczną, ambiwalencję. Wyróżniłbym może jedynie dwa utwory: Bardzo ciasny punkt widzenia i Nieznany fragment $z$ życia Dostojewskiego ze Stotnych wieczorów. Natomiast zawarta w owym tomie Zemsta podwładnego, w której tytułowa postać, sponiewierana przez zwierzchnika, dyrektora B., mającego reputację tyrana i łajdaka, zaczyna go nękać za pomoca „pozytywnej” plotki, przywodzi na myśl przedwojenne nowele Gombrowicza: Tancerza mecenasa Kraykowskiego i Studnię. Opowiadanie Dygata Księżyc z Różowego kajecika, które charakteryzują absurdalna tonacja i osobliwe gesty bohaterów, inscenizujących przy stole istne actes gratuits i maskujących czy sublimujacych w ten sposób zakłopotanie albo nieoczywistość sytuacji (z robieniem gałek z chleba włącznie), przypomina Pornografię i Kosmos. No i jeszcze aluzyjny - w stosunku do pierwotnej wersji Przygód - tytuł zbioru: Na pięć minut przed zaśnięciem.

Osobną kwestię stanowi dziennik Dygata. Dziennika w ścisłym sensie pisarz ten nie stworzył, lecz w felietonach tu i ówdzie poczynił trochę uwag, które sugerowałyby, że myślał on o konwencjach autobiograficznych nieco inaczej niż Gombrowicz. Dygat parokrotnie wyraża swoją niechęć do lansowania siebie przez twórców w autobiografiach i autokomentarzach (K 20, 107, 120; U-1 270; U-2 243247), ale też ten krytycyzm nie zawsze jest jednoznaczny. W Podróży warszawianina do Włoch kąśliwie pisze Dygat o autorze Wyznań i oskarża go o ekshibicjonizm i kabotyństwo:

Otóż i Rousseau, jakże dzięki temu nowoczesny, zwoławszy sobie uniwersalną w czasie i przestrzeni publikę, stroi przed nią sztuczne grymasy, gotów przypisać sobie najgorsze choćby łajdactwa, aby tylko ukryć bezdenną dla każdego monotonię swego naturalnego oblicza. [N 354]

W końcu wszakże stwierdza, że właśnie ekscentryczność Rousseau jest tym, co prawdziwe i interesujące dla czytelników: „każdy nosi w sobie przekonanie o swojej absolutnej inności i odrębności, a każdy w tym ludzkim rojowisku jeden do drugiego bardziej podobny, niż się na oko zdaje” (N 355). Ciekawe wątki można znaleźć w Kołonotatniku [1], rozpiętym między ambicjami diariuszowymi a dziennikarskimi. Powiada tam Dygat np.:

Szczerość jest [...] sztucznie stworzoną formułą natury salonowo-towarzyskiej, najbardziej wyrafinowaną, a więc prymitywną metodą zwodzenia bliźnich i narzucania im podstępem swoich zamysłów. [K 54]

W podobny sposób podawał argumenty często w innych miejscach: 
Nie przesadzajmy $z$ tą szczerością. Nie jest ona bynajmniej koniecznym warunkiem dobrej literatury, bowiem dobra literatura ma więcej wspólnego z naukowymi odkryciami niż z mistycznym a jałowym aktem spowiedzi. Pisarz powinien raczej coś niecoś ukrywać, niż wywalać wszystko, co posiada na zbyciu. Niech czytelnicy też się trochę pomęczą. Oni to lubią. [U-1 188; zob. też U-1 278]

Fragmenty dziennika, które Dygat zaczyna szkicować w Kołonotatniku, wyglądają na suchą rejestrację faktów, bardzo dokładną, ale może nie tak otwarta jak ta $\mathrm{z}$ Kronosa (K 124-127). Ponadto część pomieszczonych tam polemik z literatura zaangażowaną i autorytetem Pisarza (K 8), „Wielkimi Narracjami” (K 11), „,iteraturą wyczerpania” (K 23-24; tu nawet Gombrowicz ukazuje się jako wsparcie ${ }^{7}$ ) może przypominać metaliterackie filipiki autora Ferdydurki wymierzone w literaturę modernistyczną. Wydają się one tylko bardziej lakoniczne, doraźne i pozbawione zaplecza filozoficznego ${ }^{8}$.

W Jeziorze Bodeńskim rzeczona inspiracja dotyczy wielu aspektów czy płaszczyzn powieści. Wyjściowa sytuacja bohatera-narratora jest niezwykle podobna do egzystencjalnych tarapatów Józia Kowalskiego, zawróconego do szkoły i zawieszonego między teraźniejszością a przeszłością, dojrzałością a niedojrzałością, dorosłością a młodością:

Urzeczywistnia się sen trapiący do późnych lat każdego człowieka: odrywają cię niespodziewanie od ustabilizowanych zajęć dorosłego i marsz z powrotem do szkoły. Nastąpiło jakieś nieporozumienie, pokręcenie w czasie; okazało się, że przed laty nie dokonałeś wszystkich warunków szkolnych i nieprawnie poruszasz się w dojrzałości. [J 20] ${ }^{9}$

Najbardziej dojmującym doświadczeniem jest świadomość ulegania zewnętrznym presjom (J 32). W przeszłości te naciski przybierały konkretną formę pretensji ze strony rodziny - o porzucenie szkoły, o niezaradność, o brak zatrudnienia i nieokreśloność: „"...Znowu wymówki, znowu biadanie nade mną". "Patrz na innych". "Czym jesteś". "To jakaś choroba woli, brak ambicji, zginiesz marnie"” (J 117; zob. też J 34) ${ }^{10}$. Najciekawsze w tych wyrzutach jest pewnie to, że nie tylko stanowią one lekcję funkcjonowania w przestrzeni międzyludzkiej, ale też precyzyjnie określają mechanizm tworzenia tożsamości, w którym Inny to wzór i probierz („Patrz na innych”). Poczucie bierności i niemożności udziela się bohaterowi albo też pretensje rodziców są zasadne (,gdyby mi się chciało w ogóle być

7 Raz jeden pojawiają się i „ciotki kulturalne” (K 195). W Utworach rozproszonych występują sporadyczne aluzje do Gombrowicza (U-1 67, 169, 236, 259).

8 Zob. M. Bi el e cki, Literatura i lektura. O metaliterackich i metakrytycznych pogladach Witolda Gombrowicza. Kraków 2004, s. 180-275.

9 Są też i drobniejsze aluzje: oczekiwanie nie wiadomo, na co („Ale godziny mijają, pociąg nie przychodzi [...]”, J 116), sobowtór (J 217), pensjonarka wpędzająca w niedojrzałość (J 239), zieloność jako synonim niedojrzałości (J 243-244), tęsknoty przypominające homoerotyczne fantazje Miętusa, marzenie o wagarach („tą samą chętką, żeby zwagarować, uciec gdzieś nad rzeczkę, łapać motyle, na trawie się rozciągać i palić swobodnie papierosa, radując się, że nikt nie podpatruje wszelakich czynności i nie ogranicza nakazanym przez radę pedagogiczną programem”, J 19). W Pożegnaniach występują infantylizujące ciotki (Pż 52, 109, 138), pensjonarka (Pż 28), a para Mickiewicz-Janowski (Pż 7) bardzo przypomina Filidora i anty-Filidora. Pensjonarki, w tym i nowoczesne, pojawiają się w Podróży (P 39, 42, 93) oraz Disneylandzie (D 25). 
czymkolwiek?”, J 34) ${ }^{11}$. Nie bez znaczenia wydaje się ta okoliczność, że protagonista pozbawiony jest imienia i nazwiska, stanowiących w kulturowym kontekście wskazanie na tożsamościową esencję, a doznanie bierności i nieokreśloności rodzi w bohaterze wrażenie dezintegracji („Ogarnia mnie lęk niemożności odnalezienia własnej jedności [...]”, J 89), nietożsamości z samym sobą oraz nieznajomości samego siebie:

zapytuję chwilami ze zdumieniem: kim właściwie jestem? co to za istnienie? [...] Zostałem jakoś szatańsko przeinaczony w istnieniu i nie mogę się ogarnąć ani zrozumieć, co mam ze sobą poczynać. [J 26-27] ${ }^{12}$

Bohater ma poczucie alienacji, uwięzienia i osaczenia w nieco ogólniejszym czy bardziej zasadniczym wymiarze. Jest to doświadczenie podległości siłom przekraczającym jednostkową wolę, przybierającym różną postać: od wspomnianych nacisków międzyludzkich, poprzez ogólniejsze determinacje zewnętrzne, po dojmujący ciężar przeszłości. Figurę tej opresji stanowi niewola, w której się znalazł, i internowanie w gmachu szkoły, wyzwalajacym w drugich ,jakieś porzucone w dali czasu a niewyżyte sztubactwo" (J 19). To doświadczenie wyraża on omalże parafrazując Ferdydurkę: „Poza koło horyzontu nie ma ucieczki. Wszystko jest uwięzione w kole horyzontu; nie ma ucieczki [...]" (J 48-49). Kiedy indziej powie też, że „modelował swoją błazeńską gębę z gutaperki [...]” (J 218) ${ }^{13}$.

Te trudne doświadczenia rodzą w bohaterze wyjątkowe uwrażliwienie na to, co rozgrywa się w - po gombrowiczowsku nazwanej - sferze Międzyludzkiego. Perspektywa taka oznacza ujmowanie człowieka w interakcjach $z$ innymi, przy czym na ogół będą to relacje traumatyczne. To inny określa tożsamość, zmusza do stosownych zachowań, wymaga podporządkowania się wzorcom i hierarchiom, wzbudza poczucie wstydu i skazuje na nieautentyczność oraz alienację. Ponadto wszystkie interakcje pozostają zapośredniczone przez kulturowe formy, którym trzeba się podporządkować i które wywołują wrażenie konwencjonalności i sztuczności. To stąd bierze się dominująca w powieściowej poetyce retoryka teatralności - i znacząca frekwencyjność pochodnych kategorii: teatru (J 136, 187, 213-214, 236), aktorstwa (J 32-33, 38, 97, 105, 136, 214, 241), maski (J 32, 38, 66, 86, 194, 199, 241, 252), kostiumu (J 32-33, 66, 194), formy (J 29, 32, 123-124, 129, 160, 251, 257), mitu (J 35, 38-39), min (J 69, 74, 149, 171), gry (J 80, 136), sztuczności (J 143, 253) ${ }^{14}$.

11 W Disneylandzie będzie podobnie: „Ulegałem bezwolnie temu, do czego byłem przymuszany” (D 19). W Podróży Henryk Szalaj mówi o swojej „naturalnej skłonności do by c i a p o d w ł a d n y m” (P 189). Wątek ten powraca często w innych powieściach. W Disneylandzie przez aluzję Doroty do Piotrusia Pana (D 215-216). Arens później mówi do Kosmali: „Jestem "Ni to, ni owo". I ty jesteś "Ni to, ni owo". Wszyscy jesteśmy "Ni to, ni owo"” (D 224). Podobna charakterystyka pojawia się w Pożegnaniach („takie ni to, ni owo”, Pż 24), gdzie bohater również nie wie, kim jest (Pż 26), a także we fragmencie nieukończonej powieści Plac Świętego Bartłomieja (U-1 161). Tak samo w Podróży bohater ma kłopoty z poczuciem własnej tożsamości (P 38, 182).

13 W. G o m b r o w i c z użył tego określenia w Ferdydurce (Oprac. W. B ol e c ki. Kraków 2007, s. 59: „moja twarz skręciła się jak gutaperka”) i w Testamencie (w: Dziennik 1967-1969. Red. nauk. J. Bło ń s ki. Kraków 1992, s. 29: „wydany wszelkiemu najdziwniejszemu kształtowi, jak owe figurki z gutaperki dające się ugniatać na wszystkie sposoby, z których można zrobić największą potworność).

14 W innych powieściach ta metaforyka również się pojawia, ale przy niższej frekwencyjności: teatr 
Pojawiaja się nawet radykalne uogólnienia na ten temat:

Aktorstwo to altera natura. Niemowlę ma tylko naturę somatyczną, bo nie stać go jeszcze na aktorstwo. Człowiek $z$ wdziękiem to taki, który jest dobrym aktorem życia. Pozer to też aktor, tylko tyle, że zły. Zmanierowany zaś to ten, który nie może wydobyć się z szarży. [J 32]

Wydaje się jednak, że antropologiczny czy filozoficzny model podmiotowości kreowany przez Dygata różni się od Gombrowiczowskiego, charakteryzującego się performatywnością i niebinarnością. Jeśli protagonista powieściowy deklaruje: „Zachowuję własną elastyczność, własny ciężar gatunkowy nie zakłócony odważnikiem czyjegoś błędnego mniemania wywołującego terror przymusu i wymuszenia" (J 167), to łatwo w jego myśleniu rozpoznać funkcjonowanie opozycji tego, co nieelastyczne i elastyczne, tego, co niezakłócone i zakłócone, tego, co poddane błędnemu mniemaniu, i tego, co od błędnego mniemania niezależne; krótko mówiąc: przeciwstawienie tego, co nieautentyczne, i tego, co autentyczne, oraz wiara w jakiś głęboki wymiar podmiotowości za „murem formy” (J 255). Taki wymiar miałby się ujawniać zwłaszcza w trakcie pewnych szczególnych wydarzeń i wówczas człowiek odsłaniałby „siebie samego”, demaskowałby „siebie do właściwej swojej postaci, związanej konsekwentnie z przeszłością i przyszłością" (J 79). A to by znaczyło, że istnieje w nim swego rodzaju niezmienna esencja, określająca jego tożsamość i determinująca losy. Kiedy ona dochodzi do głosu, to „Nie ma już miejsca na osłanianie się gierkami, są tylko bezpośrednie starcia prawdziwych stylów [...]” (J 79). Na ogół jednak dzieje się tak, jak w obozie internowanych, i wtedy:

Nie jest się sobą, zaledwie reprezentuje się siebie. Reprezentacja jest zwodna, improwizowana, łatana $z$ najrozmaitszych kawałów przeżyć, często nie dokonanych, ba, może nawet nie siebie się prezentuje, ale w ogóle człowieka, jakieś tam ogólne pojęcie człowieka. [J 79-80] ${ }^{15}$

Doda też bohater-narrator, że czasem tej sytuacji nie wytrzymuje i usiłuje „odnaleźć w sobie coś własnego, co nie tylko jest ogólnym pojęciem człowieka jawiącego się zależnie od jawienia się innych ludzi [...]". Niczego takiego wszakże nie odnajduje i opanowuje go jedynie „paniczny lęk” ( J 80). A mimo to protagonista Jeziora Bodeńskiego nie przestaje wierzyć, że nie wszystko w tej mierze stracone:

Trzeba tylko odróżnić wewnętrzne oblicze człowieka, gdzieś tam szczelnie ukryte przed wzrokiem bliźnich, które jest względnie niezmienne i niezależne, od żywotności zewnętrznej, przypadkowej, schlebiającej okolicznościom, uwarunkowanej tym i owym, złudnej i ustawicznie nie na serio. To, co się nazywa odmianą człowieka, jest tylko czystą formalnością: przystosowaniem i prawdziwym odwzorowaniem żywotności zewnętrznej do zasadniczego odbicia wewnętrznego. [J 248]

Wedle owej wykładni człowiek ma zatem dwie sfery: wewnętrzną i zewnętrzną, które należy od siebie oddzielać. Pierwsza pozostaje skrzętnie ukryta przed inną osobą, posiadającą dostęp jedynie do sfery zewnętrznej. Owa opozycja nie jest symetryczna i jej pierwszy człon dominuje nad drugim hierarchicznie oraz aksjologicznie. Pozostaje czymś niezmiennym, niezależnym i nie poddającym się przygod-

(D 150), aktor (Pż 54, 124), maska (D 142; P 95; Pż 153, 158), forma (Pż 123, 153), gra (D 91, 137, 150), sztuczność (D, 158; P 95; Pż 19, 57).

15 Przy innej okazji protagonista zauważy, że tą kategorią chętnie posługują się Niemcy: „Oni kopią i maltretują nie danego człowieka, ale pojęcie człowieka, ideę człowieczeństwa” (J 106). 
nym oportunizmom. Stanowi domenę prawdy, w której zdeponowane jest to, co najcenniejsze, czyli to, co naturalne i idiomatyczne. Takie przypuszczenie potwierdza sposób operowania przez Dygatowego rezonera opozycją duszy i ciała: „Nie ma wolności dla tej duszy ubranej w przyciasny strój ciała [...]" (J 140-141). Następnym razem zastanawia się on, co dzieje się „pod tym zdawkowym kostiumem postaci cielesnej, maskującym i przekręcajacym zwodniczo istotę rzeczy" (J 194-195). I snuje rozważania dalej:

Właściwie cała ta doczesna powłoka, jak by powiedział ksiądz Cléont, służy tylko do oszukaństw i skrywania się przed bliźnimi. [...] Sądzę, że to właśnie ta straszliwa niewola duszy za kratkami grymasów, błysków, gestów i wyrazów stwarza ten stan nie do zniesienia, zwany ludzką egzystencją. [...] Bo tutaj uciskane ciało traci od czasu do czasu cierpliwość i wyrzucone na moment z toru swojego schematyzowanego stylu ukazuje jakiś fragment wnętrza, którego nikt by się po nim nie spodziewał. [J 195]

Ta domieszka języka religijnego ewidentnie sytuuje filozoficzną wyobraźnię Dygata w opozycji do Gombrowicza, któremu bliższy byłby pogląd Michela Foucaulta: „dusza więzieniem ciała” ${ }^{16}$. Nie jedyny to ascetyczny rys w myśleniu autora Jeziora Bodeńskiego.

Bohater Dygata wyciaga $z$ tych założeń dość radykalne wnioski. Nie tylko postrzega swoje doświadczenia w kategoriach teatralnych, ale $\mathrm{z}$ premedytacja performatywnie kładzie nacisk na ich inscenizowany charakter. Ustawicznie odgrywa jakieś role, cały czas uruchamia pewne scenariusze, podkreślając swój dystans do nich i eksperymentując zarówno $z$ ideami, jak i z ludźmi. Unika absolutyzowania rozróżnień na prawdę i fikcję, rzeczywistość i fantazję, powagę i niepowagę. Nie czyni tego jednak w lekkim, „ferdydurkicznym” stylu. Ponadto - o ile Józio Kowalski stawał się w miarę rozwoju powieściowych zdarzeń coraz bardziej niezależny, a jego akcje coraz bardziej subwersywne, o tyle bohatera Dygata stać wyłącznie na bycie pretensjonalnym, drażliwym, roszczeniowym i mściwym ${ }^{17}$. Wydaje się, że pod tym względem bliżej mu do zbiorczo ujętego bohatera Pamiętnika z okresu dojrzewania, zwłaszcza w jego charakterystyce sporządzonej przez Janusza Margańskiego $^{18}$. Nawiązanie do debiutanckich opowiadań antenata oznacza jednocześnie zapośredniczenie inspiracji, której źródłem jest twórczość innego pisarza ważnego dla Dygata. Chodzi, oczywiście, o Fiodora Dostojewskiego. To bohaterowi Wspomnień człowieka $\mathrm{z}$ lochu część protagonistów Pamiętnika z okresu dojrzewania i większość protagonistów Dygata zawdzięczać będzie swoje zasadnicze rysy ${ }^{19}$. Jedną z najważ-

M. F o u c a u lt, Nadzorować i karać. Narodziny więzienia. Przekł., posł. T. K o m e n d a n t. Wyd. 2. Warszawa 1998, s. 31.

Protagoniści późniejszych powieści Dygata myślą bardziej radykalnie. Paweł z Pożegnań wyznaje: „Od dawna już żyłem w niezgodzie z otoczeniem. Miałem wstręt do szablonów i schematów wzajemnego obcowania ludzi ze sobą, prześladował mnie ustawiczny odruch korygowania na własną rękę wszystkiego, co wydawało mi się w życiu niesłuszne, fałszywe i niesprawiedliwe, a wreszcie już przez samą przekorę postępowałem na przekór wszystkiemu, co widziałem dokoła. Rzecz prosta, panujący układ międzyludzkich stosunków był silniejszy od jednostkowego działania protestów, które kończyły się zazwyczaj porażką moją, a zdumieniem opinii publicznej [...]” (Pż 9). Jako szczególnie inspirujące można potraktować zasugerowanie związków „normalności” i antysemityzmu (Pż 13). J. Ma r gań s ki, Gombrowicz wieczny debiutant. Kraków 2001, s. 66-79, 93-100.

Tę zależność już zauważano - zob. J an uszki ewi c z: Tropami egzystencjalizmu $w$ literaturze polskiej XX wieku, s. 110, 117, 123, 129-130, 133-134, 143, 145, 148, 176; Stanisław Dygat, 
niejszych cech bohatera Dostojewskiego stanowi strategia autokompromitacji. Wyznawał on:

Jestem człowiekiem chorym. Jestem złym człowiekiem. Niepociagający ze mnie człek. [...]

Marny był ze mnie urzędnik. Byłem ordynarny i znajdowałem w tym zadowolenie. [DW 7]

bom gałgan, najohydniejszy ze wszystkich, bom najśmieszniejszy, najmałostkowszy, najbardziej zawistny ze wszystkich robaków na ziemi [...]. [DW 121]

Powiadał też, że cierpi na chorobę świadomości, która unieszczęśliwia (DW 37), i że swój „loch nosi w swojej duszy” (DW 50). Przekonuje zarazem, iż najszczególniejsze cechy osobowości dzieli z większością sobie współczesnych. Tutaj na bardziej ogólnym poziomie Dostojewski mierzy w utopię socjalistyczną i sprzeciwia się moralności ufundowanej na koncepcji racjonalizmu, na zasadzie utylitaryzmu oraz pojęciu „wolnej woli” (DW 30, 34), dowodząc ustami swojego bohatera, że pozostaje ona czymś zawsze uwarunkowanym zewnętrznymi kontekstami. Okoliczności te przesądzają także o jego nieokreślonej tożsamości:

Nie tylko złym, ale zgoła żadnym nie potrafiłem się stać: ani złym, ani dobrym, ani podłym, ani uczciwym, ani bohaterem, ani owadem. [...] Otóż to, człowiek dziewiętnastego stulecia winien i jest moralnie zobowiązany być stworem przeważnie pozbawionym charakteru; człowiek zaś posiadający charakter, działacz - przeważnie bywa stworem ograniczonym. [DW 9]

A jednak te właściwości nie świadczą, że jest on zupełnie bierny. Decyduja natomiast o bardzo osobliwych strategiach postępowania. Bohater wyznaje, że przez 40 lat żyje w samotności (DW 44), „nieprzyzwoicie, poniżająco, niemoralnie” (DW 9), zanurzajac się „w ponurej, kreciej, wstrętnej - nie rozpuście, tylko rozpustce” (DW 50). Co to wszystko oznacza? Otóż nie tyle skłonność do transgresji, ile perwersyjne zainteresowanie podłością, nikczemnością oraz inscenizowaniem sytuacji kompromitujacych:

dlaczego zdarzało się tak, że jakby naumyślnie w momentach, w tych właśnie momentach, podczas których byłem najbardziej uzdolniony do uświadamiania sobie wszystkich subtelności „tego, co piękne i wzniosłe", jak się to ongi u nas mówiło, że właśnie wtedy zdarzało mi się już nie uświadomić sobie, lecz popełniać takie nieprzystojne czyny... takie, które... no tak, słowem czyny, które chociaż zapewne wszyscy popełniają, lecz które, niby naumyślnie, wymykały mi się właśnie wtedy, gdym najdokładniej uświadomił sobie, że tego nigdy nie należałoby czynić? [DW 11]

Ukazuje to też osobliwy stosunek do samego siebie oraz do innych. $Z$ obsceniczną rozkoszą przeżywa bohater własne ubóstwo, pohańbienie i poniżenie (,rozkosz powstawała w tym wypadku na tle właśnie zbyt ostrego uświadomienia sobie swego poniżenia [...]”, DW 12). Nie przeszkadza mu to równocześnie $z$ mściwą satysfakcją odreagowywać na innych doznane upokorzenia. Traktuje ich z zawiścią i pogarda, cynicznie nawiązuje relacje i je zrywa. Tak postępuje z jednym z nielicznych przyjaciół, $z$ którym kończy znajomość w momencie jego absolutnego oddania się jemu (DW 69). Opowiada o tych relacjach przy użyciu kategorii pana i niewol-

s. 28, 58, 69, 75-76, 94. Zob. też G. D e le u z e, Nietzsche i filozofia. Przekł., posł. B. B a n a s i a k. Warszawa 1993, s. 123-129. - F. N i et z s c h e, Z genealogii moralności. Pismo polemiczne. Przeł. G. Sowiński. Wstęp K. Mi chalski. Kraków 1997. - R. Przybylski, Dostojewski $i$ „przeklęte problemy”. Warszawa 2010, s. 115-151. 
nika, dominacji i podporządkowania. W taki sposób obchodzi się z młodą prostytutką Lizą. $Z$ szyderczą intencją zaczyna ją dręczyć historyjkami o miłości prawdziwej i występnej, idealnej i sprzedajnej, $z$ sadystycznym zacięciem mami obietnica wyrwania jej z marnej egzystencji. Czyni to dla zabawy („To gra, gra wciagała mnie”, DW 102) i dla odreagowania własnych upokorzeń przez poniżanie nieszczęśliwej dziewczyny. Wyznaje wprost: „Panowania, panowania trzeba mi było wówczas, zgrywania się było mi potrzeba, łez twych, poniżenia, histerii twojej [...]” (DW 120). W głowie ma natomiast swoje ulubione fantazje moralistyczne:

Za to teraz raptownie uderzyła mnie $\mathrm{z}$ niezwykła jaskrawością absurdalna, odstręczająca niczym pająk, idea rozpusty, co bez miłości, w sposób brutalny i wyuzdany, zaczyna wprost od tego, czym prawdziwa miłość zwykła wieńczyć. [DW 88]

Jako się rzekło, powieściowi protagoniści Dygata będą tej umiarkowanie sympatycznej kreacji zawdzięczali swoje rysy ${ }^{20}$. Bohater-narrator Jeziora Bodeńskiego $z$ dużą konsekwencją autokreuje się na outsidera, nigdzie nie przynależącego, mającego trudności $z$ identyfikacją $z$ wartościami oraz z integracją ze wspólnotą, a prowadzonego przez los nie „otwartym gościńcem zdarzeń, ale raczej boczną ścieżką, po której wszystko toczyło się niby tak, jak normalnie w życiu, jednak w odmiennej skali, $\mathrm{z}$ niedbalstwem odtworzenia lub fragmentarycznie - bez ostatecznego dokonania” (J 11). Podkreśla wielokrotnie, że jego życie przepojone było tylko niespełnieniem, niedokonaniem i zaniechaniami, tak w miłości i erotyce, jak też w życiu publicznym. Relacje międzyludzkie stanowiły natomiast ciag przykrości i upokorzeń. Bohaterowi tej powieści nie dane było zaznać sytuacji, w których mógłby zaświadczyć o swojej dojrzałości, niezależności czy decyzyjności. Przeciwnie, okoliczności potencjalnie transgresyjne zmieniały się nieoczekiwanie w groteskowe i absurdalne - i pogłębiały samozatrucie. Tę strategię autokompromitacji zrealizuje on bardzo konsekwentnie w retoryce teatralności, dodatkowo wzmagającej wyobcowanie i rozgoryczenie:

byłem zawsze jedynie aktorem odgrywającym źle i bez przekonania narzuconą rolę, napisaną w sposób niezdarnie naśladujący rzeczywistość, nigdy - jak inni - bohaterem autentycznych zdarzeń [...]. [J 12]

Tak samo we wstępie do odczytu o Polsce zasugeruje swoją niedojrzałość i mierność (J 273). Jednocześnie będzie mu ta osobliwa taktyka przynosiła obsceniczną rozkosz: „Można się samemu poniżać i nawet w poniżeniu znajdować niejaką satysfakcję" $(\mathrm{J} 85)^{21}$. Ale równie wiele zadowolenia daje mu sprawianie przykrości i psucie dobrego samopoczucia innym (J 30).

Dygat wyzna: „Co do mnie, nie nadaje się do opisywania pozytywnych bohaterów. Ułomności i grzechy wyostrzyły moją wrażliwość na to, co sztuczne, fałszywe i niedoskonałe” (K 63). Jedną $\mathrm{z}$ rzadkich sytuacji, w których to usposobienie przynosi inspirujące intuicje, jest ta z Podróży. Henryka Szalaja niechęć do sztuki jest zasilana resentymentem i upokorzeniem (P 7-8), ale też pozwala na przenikliwe rozpoznanie związków sztuki, polityki i władzy (P 8) oraz drobnomieszczańskiego aspiranctwa do obcowania ze sztuką jako kojącego lęki egzystencjalne (P 9). Bohater Dygata zdaje sobie również sprawę z tego, co nazywane bywa kapitałem kulturowym (P 50). Trochę w stylu Gombrowicza mówi też o obowiązkach pisarza (P 9).

21 W późniejszych powieściach będzie podobnie. Bohater Disneylandu wyzna wprost: „Wiedziałem, że jestem zerem" (D 196). Strategia autokompromitacji pojawia się w Karnawale (KD 18) i w opo- 
Najjaskrawiej skłonności te ujawnią się w relacjach z kobietami. Bohater Jeziora Bodeńskiego tak zapytuje samego siebie:

Czemu Suzanne nie usiłuje [...] zlekceważyć mnie i dawać do zrozumienia, że z takim zerem jak ja długo nie wytrzyma. Do tego przyzwyczaiły mnie wszystkie kobiety, w których się kochałem, i z tym było mi dobrze. [J 78-79]

A jednak nie sposób jego zachowań sprowadzić do resentymentowej zemsty za odrzucenie. Jest dokładnie na odwrót, to bohater z psychopatyczną konsekwencja nawiąuje relacje $\mathrm{z}$ kobietami, lekkomyślnie rozkochuje je $\mathrm{w}$ sobie, a następnie porzuca, wyrzekając się wszelkiej odpowiedzialności. W takiej mierze jego niedojrzałość nabiera konkretnego albo dosłownego sensu. Co więcej, nie tylko porzuca je, ale dokonuje tego w bezlitosnej grze, w której wiele jest $z$ asekuranctwa, kabotyństwa i prawdziwego okrucieństwa. Bohater upokarza tyleż siebie, karmiąc się niespełnieniem, co i kolejne partnerki, czerpiąc największą satysfakcję właśnie z odrzucania i odpychania. Nie przychodzi mu to łatwo, bo cały czas balansuje między nadzieja a rozczarowaniem, kompulsją a depresją, euforią a załamaniem, masochizmem a sadyzmem. Tak jest w dłuższym, toksycznym związku z Ludką toksycznym, bo oboje zdają się naprawdę siebie nie lubić, zarzucając sobie wzajem nieszczerość i często raniąc się obojętnością ( J 33) - jak i w krótkim romansie z Suzanne, która to relacja sprawiać mogła wrażenie opartej na autentycznych uczuciach. Nic podobnego. Francuzkę będzie bohater dręczył z wielką konsekwencją: najpierw $\mathrm{z}$ upodobaniem wpędzając ją w zakłopotanie (J 56), w końcu z sadystyczną przyjemnością odtrącając zakochaną w nim kobietę i ostentacyjnie kokietując w jej obecności fordanserkę Renée. „Niech cierpi [...]” (J 84) - te słowa powtarza sobie pięć czy sześć razy. Jednocześnie przyznaje się sam przed sobą, że wszystko to wyłącznie blaga i gra $(\mathrm{J} 65,67)^{22}$.

Powody tych odrzuceń zdają się wynikać z lekcji wyczytanej u Gombrowicza. Bohaterowie Dygata często sugerują opresywny charakter relacji z kobietami. Protagonista Jeziora Bodeńskiego będzie się skarżył na drażniący, zawstydzający wzrok Suzanne (J 22). Innym znów razem spojrzenie kobiety wywoła w nim „zimny skurcz wstydu” (J 78). Powie też, że miłość to „unieruchomienie w cudzej rzeczywistości” (J 249) i że jest czymś uwłaczającym („Poniża mnie uczucie [...]”, J 60) ${ }^{23}$. Ponadto Suzanne miałaby wymagać mężczyzny „o silnym ramieniu, które otacza słabą kibić” (J 240). Tymczasem on zupełnie inaczej wyobraża sobie męskość:

moje poczucie męskości zawiera się w czymś wręcz innym jak w otaczaniu silnym, męskim ramieniem drżącej subtelnością słabej i niewinnej kibici. [...] właśnie to połączenie silnego ramienia $z$ niewinną kibicią to coś, od czego dostaję uczuciowych mdłości, jakiś oszukańczy wabik natury, który w parę sekund może dokonać, że z twoją wzniosłą subtelnością i niewinnością staniesz się czymś tak poczwarnie śmiesznym, zmiętym i wcale nie wzniośle usatysfakcjonowanym, że będziesz budziła litość jak żebraczka, która głośną litanią wyżebrała jałmużnę. [J 84]

wiadaniach: Jesień (N 18) z tomu Pola Elizejskie oraz Nie wzdychać za tym, co nierealne (N 149) ze Stotnych wieczorów.

22 Taki rytuał, tym razem w obecności Suzanne, zainscenizuje w jeszcze okrutniejszej formie bohater Karnawału, poniżając Dankę (KD 35).

23 Identycznie w Disneylandzie relację z Aliną będzie przeżywał Arens (D 26). 
Z kolei w relacji $z$ Renée bohater-narrator będzie czuł się infantylnie „upupiony” („To pani jest pensjonarka i wciaga pani człowieka w swoją pensjonarskość”, J 239) ${ }^{24}$. Niektóre wynurzenia bohatera sugerowałyby kompensacyjna i lękową podstawę relacji z kobietami. Oto najpierw wyznaje on z nadzieją, że przychylność „takiej kobiety” mogłaby mu dodać animuszu (J 61), ale później potwierdza, że obawia się uzyskać pewność siebie dzięki kobiecie (J 66). To by jednak znaczyło, iż bohater był pozbawiony tej pewności, a w każdym razie tego, o czym myślał mówiąc o niej. Czy więc chodzi tu o coś innego niż o obawę przed formą? I jak miałoby wyglądać owo inne od tradycyjnego wyobrażenie męskości? No i dlaczego Janka nazywa go „zniewieściałym Francuzem” (J 291)?

Czynnikiem destabilizującym tożsamość męską jest u Dygata skłonność protagonistów do roztkliwiania się i rozczulania się nad sobą. „Zatapiam się w żalu i tkliwości dla samego siebie" (J 236) - wyznaje bohater-narrator Jeziora Bodeńskiego. Eve Kosofsky Sedgwick, śledzac kulturowy dyskurs dotyczacy sentymentalności, wspomniała Friedricha Nietzschego refleksje nad resentymentem i zauważyła, że odkrywał on „w tych pozornie prostych i przejrzystych bodźcach skomplikowane i ruchome warstwy złożone na przemian $z$ pragnienia wielkości i rozkoszy oraz ze zwróconej ku sobie pogardy i $z$ altruizmu" 25 . Owe wewnętrzne konflikty najpełniej dochodzą do głosu w wyobrażeniach bohaterów na temat kobiet. Istnieją one w powieściowych światach Dygata wyłącznie w imaginacji mężczyzny jako fantazmat i nie wykraczaja poza stereotyp, balansując między banalnymi wzorcami Madonny i Ladacznicy ${ }^{26}$. Wbrew wszelkim pozorom ta ambiwalencja jest w całości mizoginiczna. Opiera się bowiem na specyficznym postrzeganiu seksualności kobiecej jako czegoś nieczystego i grzesznego. Reprezentuje ją zdemonizowany wzorzec Ladacznicy, to uosobienie nieumiarkowania, niestałości, bezwstydu, występności, rozpusty, rozwiązłości, lubieżności i - ogólnie rzecz biorąc - wszelkiej dekadencji. Tu kobieta jest zagrożeniem, a mężczyzna przez kontakt $z$ nią ryzykuje deprawacją i upadkiem moralnym. Natomiast Madonna to wzniosły archetyp kobiecości niewinnej, ascetycznej, purytańskiej, całkowicie wyabstrahowanej z cielesności i seksualności. To dziwaczne rozdwojenie kobiecości oddaje pewne konflikty psychiczne mężczyzn, w których stosunku do kobiet miesza się pochwała i potępienie, gloryfikacja i pogarda, lęk i nienawiść, wstyd i odraza, pożądanie i obrzydzenie ${ }^{27}$. Tacy są wszyscy męscy protagoniści wymyśleni przez Dygata.

Te zbanalizowane przeciwstawienia uruchamiaja w umysłach męskich proste skojarzenia i sztywne aksjologie w postaci tradycyjnych ukazań ideału i rzeczywi-

24

W Podróży prostolinijna Jadzia wyznająca Henrykowi naiwnie miłość zostanie posądzona o dybanie na ,jego fizyczną całość” i bezceremonialne „pretensje do niepodzielnych praw intymności” (P 83).

25 E. Kos of sky Sedgwick, Wilde, Nietzsche i sentymentalne zwiazki z męskim ciałem. Przeł. B. Warkocki. Współpr. P. Cza plińs ki. „Teksty Drugie” 2012, nr 5, s. 95.

26 Zob. J a n u s zki ew i c z: Tropami egzystencjalizmu w literaturze polskiej XX wieku, s. 154-166; Stanisław Dygat, s. 103-123.

27 D. L. Gilmore (Mizoginia, czyli Męska choroba. Przeł. J. Margań ski. Kraków 2003, s. 212) syndrom Madonny-Ladacznicy wyjaśnia przede wszystkim w kontekście Freudowskiego schematu edypalnego. Według niego mężczyzna poniża obiekt seksualny, aby ocalić własną relację z matką, która to relacja powinna być wyabstrahowana $z$ wszelkiej seksualności. 
stości, wyobrażeniowego i realnego, spełnienia i niespełnienia, tajemnicy i jawności, prawdy i nieprawdy ${ }^{28}$. Parafrazując Jacques'a Derridę, czytającego Nietzschego, powiedzieć by można, że bohater Dygata szuka kobiety nie w tym, co kobiece, ale w kobiecości, którą stanowią „kobiecość kobiety, seksualność kobieca i inne esencjalizujące fetysze, będace właśnie tym, co, jak można sądzić, bierze się, gdy pozostaje się przy głupocie filozofa dogmatyka, bezpłodnego artysty lub niedoświadczonego uwodziciela"29. Dygat i jego bohaterowie myślą także i tutaj w formie mocno zbinaryzowanej i wszystkie konsekwencje takiego myślenia kształtuja jego/ich wyobrażenia na temat kobiecości. Ambiwalencje charakteryzujące relacje protagonistów mają związek $\mathrm{z}$ tym, że w tradycyjnej metafizyce naszej kultury kobieta ,jest dwukrotnie modelem, jest nim w sposób sprzeczny, wychwala się ją, a zarazem potępia" ${ }^{30}$. Jako model prawdy wykorzystuje ona uwodzicielska moc i sprowadza na manowce zarówno sceptycznych filozofów, jak i bardziej naiwnych mężczyzn. Zarazem jednak kobieta nie wierzy w prawdę i dlatego jej domena jest „udawanie, strojenie się, kłamstwo”31. Niewątpliwie to takie cechy, jak „uwodząca odległość, czarująca niedostępność, nieskończenie zawoalowana obietnica, transcendencja wytwarzająca pożądanie, Entfernung [...]"32 rozpalają pożądanie protagonisty Jeziora Bodeńskiego (i bohaterów późniejszych powieści ${ }^{33}$ ), który bezceremonialnie wyznaje:

Tak w późniejszych latach, gdy znalazłem się na koniec sam na sam z kochanką, po pierwszym zaznaniu pieszczot pragnałem czym prędzej uciec od niej i pozostać ze sobą, aby znów móc o niej marzyć. [J 37-38]

\section{Jednocześnie:}

Kobieta jest [przez mężczyzn] potępiana, poniżana, pogardzana jako postać lub moc kłamstwa. Kategoria oskarżenia zostaje zatem wytworzona w imię prawdy, dogmatycznej metafizyki, łatwowiernego mężczyzny, który wysuwa prawdę i fallus jako swe własne atrybuty. Teksty - fallogocentryczne pisane na gruncie tej reaktywnej instancji są bardzo liczne ${ }^{34}$.

Utwory Dygata mieszczą się w owej bibliotece. Nie ulega wątpliwości, że świat w nich przedstawiony to męski świat ze wszystkimi tego konsekwencjami. To świat mężczyzn, ich problemów i interesów, ich pasji i wyobrażeń, ich rywalizacji i solidarności. To świat sportu, romansów, historii i polityki. Tak jest w większości powieści Dygata i tylko w Jeziorze Bodeńskim sprawy mają się odmiennie. Bohater sam zauważa, że wraz z innymi mężczyznami znalazł się w „mało męskiej niewoli” (J 218). Powie też: „Tu nie ma mężczyzn ani spraw męskich” (J 284). Na dodatek

Najbliższy bohaterowi Dostojewskiego jest protagonista Dworca w Monachium: „W tej [...] sferze przeżyć uprawiałem małą, plugawą rozpustę i marzyłem o wielkiej, czystej miłości” (KD 53).

J. De r rid a, Ostrogi. Style Nietzschego. Przeł. B. B a n a si a k. Gdańsk 1997, s. 23.

Ibidem, s. 33.

Ibidem.

Ibidem, s. 48-49.

Cechy wymienione przez Derridę wzmagaja pożądanie nawet u samego autora, bo w ankiecie Kobieta mojego życia, czyli... test na odwagę stwierdzał on banalnie: „Poza tym kobiety nie powinniśmy poznawać tak zupełnie do końca, musi pozostać coś niedopowiedzianego. Wtedy czar trwa długo" (U-1 245).

Derrida, op. cit., s. 54 . 
także ich tożsamości narodowe nie wydają się szczególnie stabilne, bo wyglądają oni na gromade „poczwarnych wybryków natury paszportowej i narodowościowych bękartów" (J 23). Faktycznie, towarzystwo to przedstawia się jako dziwaczna, tyleż infantylna, co sklerotyczna, grupa facetów oddających się bez końca dyskusjom, rezonerstwu, rywalizacjom i popisom. Podobnie jak u Gombrowicza - jest to rzeczywistość homospołeczna, z taką tylko różnicą, że ten męski ład choć znajduje się na granicy zapaści, nigdy nie zostaje zrujnowany, a ponadto nie ma w nim stematyzowanej relacji homoseksualnej. Tak jakby u Dygata istniał wyłącznie jeden biegun homospołecznego kontinuum. Istnieje on jednak bardzo intensywnie w postaci silnych więzi między mężczyznami i relacji rywalizacji, przyjaźni oraz braterstwa. Z lektury prac m.in. Girarda i Kosofsky Sedgwick wiadomo, że w tej mierze nie każda rzecz jest tak oczywista, jak chciałaby mądrość powszechna, i że wiele w tym wszystkim ambiwalencji, mocno komplikujących standardowe rozróżnienia tradycyjnego dyskursu na temat płci. Nawet jeśli sa to zależności strukturalne, a nie sublimacyjne, to jednak dzieje się tak, że im bardziej coś jest homospołeczne, tym bliższe homoseksualności. Owe więzi to konieczność, nie można być ich pozbawionym, ponieważ wówczas przestaje się być mężczyzną. Prawdziwym mężczyzną przestaje się być wtedy, gdy relacje tu omawiane zaczyna naznaczać pożądanie.

Na pozór w literackich światach Dygata nic takiego nie następuje. Co nie świadczy o tym, iż bohaterowie męscy nie przeżywają tożsamościowych huśtawek i nie muszą stabilizować swojej tożsamości w jakiś sposób. Wiadomo, że na ogół takie niejasności rodza przemoc i dyskryminację, które sa w istocie egzorcyzmem ${ }^{35}$. U Dygata w męskich relacjach nie pojawia się pożądanie homoseksualne, nie ma więc i przemocy bezpośredniej, sporo jest jednak zachowań wyglądających na prewencyjne egzorcyzmowanie tego, co mogłoby zakłócić postrzeganie samego siebie jako mężczyzny. Bywają momenty tak silnej interakcji między mężczyznami, iż konieczne okazuje się ustabilizowanie tożsamości. Nie ma homofobicznej przemocy, ale jest silny mizoginizm ${ }^{36}$. Stosunkowo najmniej dzieje się w Jeziorze Bodeńskim, aczkolwiek jest to tekst pod tym względem paradygmatyczny dla pisarstwa Dygata.

Po pierwsze, relacje między mężczyznami charakteryzują się intensywnością, a niektóre nawet bardzo dużą afirmatywnością. Bohater zdradza np. fascynację szorstką męskością marynarzy $(\mathrm{J} 77,109)$. Po drugie, pojawia się struktura, która będzie stale istnieć w późniejszych utworach. Tak się bowiem składa, że partnerzy wybranek Dygatowych protagonistów w szczególny sposób poruszają ich wyobraźnię. Kazika, następnego kochanka Ludki, bohater Jeziora Bodeńskiego zdążył polubić i znielubić (J 131). Z kolei w wyjaśnieniu protagonisty Roullot broni się przed zdziecinnieniem starczym próbą poderwania Renée, wcale jednak nie chodzi mu

Zob. E. Ko s of s ky Sedgw i ck, Between Men. English Literature and Male Homosocial Desire. New York 1985.

36 Najprawdopodobniej to nie sprawa przypadku, że protagoniści Jeziora Bodeńskiego (J 25) i Disneylandu (D 193) cenią J. Brahmsa, o którym wiadomo, iż był wyjątkowym mizoginem. Na ten temat zob. Gilm or e, op. cit., s. 180-185. Mizoginizm jest najwyraźniej zaraźliwy, bo udziela się komentatorom, czego niezły dowód mogą stanowić fragmenty książki Skwarczyńskiego. Gwoli przykładu - jeden cytat à propos bohaterek Dygata: „Realistyczna teza, że akt seksualny równa się wypiciu szklanki wody, sformułowana została stosunkowo niedawno, ale kobiety hołdowały jej chyba od wieków" (S kw a r c zyń s ki, op. cit., s. 142). 
o nią: „zdobyć kobietę, która interesuje przyjaciela, i to w jego własnej muszce, oto prawdziwie chwalebna racja do odzyskania zagubionego gdzieś wieku męskiego" (J 243). Klasyczne ustalenia Girarda nieźle objaśniaja to, co się w takim przypadku rozgrywa ${ }^{37}$. Jak wiadomo, francuski antropolog opisał paradygmatyczne - dla zachodniej metafizyki płci i narracji o miłości - ustrukturyzowanie relacji między płciami. W szeregu dzieł klasycznych (choćby M. de Cervantesa, Stendhala, M. Prousta) przybiera ono formę pragnienia „mimetycznego” i „trójkątnego”. To sytuacja, w którą uwikłanych zostaje dwóch mężczyzn rywalizujących o jedną kobietę - w tej relacji stanowi ona niesamoistny przedmiot pożądania. Mówiąc krótko: pragnienie jest naśladowaniem pragnienia, a pożąda się tego, czego już ktoś pożąda. Charyzma konkurenta przydaje atrakcyjności i powabu obiektowi pragnienia. W konsekwencji relacje między mężczyznami stają się intensywniejsze, a kobieta podlega osobliwej redukcji oraz wpisaniu w struktury rywalizacji i władzy męskiej.

Jako się rzekło, zapowiedzi z pierwszej powieści znajdą pełniejszą realizację w następnych utworach. Najdalej od akceptowanego bieguna homospołecznego kontinuum sa prawdopodobnie Pożegnania, gdzie bohater raz po raz sugeruje swoją słabość do „chłopców” (Pż 11-14, 25-26), do których nawet w jednym z komplementów porównuje Lidkę (Pż 26). Zdarzają mu się ponadto deklaracje zastanawiające: „Przyznam się, że w ogólności uwodzenie dziewcząt zdawało mi się zajęciem jałowym i nużącym” (Pż 19). Są też relacje ewidentnie mimetyczne. Tak więc Paweł stworzy taki trójkąt $z$ Marcelem i Dodo, nie mając większych oporów z wyznaniem, iż Marcel Cachard mu się podoba (Pż 73). Lidka jest fordanserką, co znaczy także, że jest kobietą najdosłowniej dzieloną $z$ innymi mężczyznami.

$\mathrm{Z}$ bodaj jedynym przejawem lęku przed homoseksualnością spotykamy się w Disneylandzie, w odniesieniu do Szymaniaka, z którym Marek Arens jest w iście platońskiej relacji przyjaźni: „Szymaniak miał do mnie stosunek tak serdeczny, że zastanawiałem się czasem, czy nie jest pedałem" (D 19). Lecz okazało się, iż obawy były bezzasadne, a Szymaniak stał się wręcz sojusznikiem w „walce płci”:

Nie był pedałem, ale miał urazy w stosunku do kobiet. Ta zdzira była pierwsza jego kobietą w życiu. [...] Gdy nieświadomość zderzy się z rozbudzoną nagle namiętnością, wynikają z tego okropne rzeczy. [D 19-20]

Trudno powiedzieć, co myślał bohater, mówiąc o nieświadomości i namiętności. Natomiast za jedna $z$ „najokropniejszych rzeczy” wolno chyba uznać próbę zamordowania Loli „Fiat 1100” w zemście za doprowadzenie do samobójstwa Szymaniaka, za co Arens w zakończeniu powieści zostaje skazany na więzienie. To Szymaniak będzie też stanowił wzór męskości dla Arensa. Co jednak bardzo ciekawe: nie miał ów wzór nic wspólnego ani $z$ tradycyjną męskością w stylu gentlemańskim, ani z najnowszymi modelami męskości, które trudno odróżnić od modeli kobiecości (D 81). Ten aprobowany wzorzec męskości wyznacza postać księcia Niechludowa ze Zmartwychwstania Lwa Tołstoja, tak jak go zinterpretował Szymaniak. Poza tym w powieści pojawia się cały szereg relacji w trójkącie. Pierwszy trójkąt Arens utworzy z Aliną Wagner i Arturem Wdowińskim, do którego będzie miał ambiwalentny

37 R. Gir a rd, Prawda powieściowa i kłamstwo romantyczne. Przeł. K. Ko t. Warszawa 2001, s. 7-57. Zob. też Kos of sky Sedgwick, op. cit., s. 21-22. 
stosunek - mieszają się w nim zazdrość, szacunek i sympatia (D 24-25). W pewnym momencie wraz $\mathrm{z}$ konkurentem będzie też szydził z porzuconej przez obu dziewczyny (D 25). Przyszły jej mąż jako sportowy fan będzie szalał za Arensem (D 27). O Agnieszkę będzie $z$ Leonem Kozakiem rywalizował Marek, w ogóle nie interesując się wyglądem dziewczyny (D 42-43).

Można odnieść wrażenie, że przynajmniej w tej pierwszej scenie bardziej zajmuje go Leon, przystojny koszykarz i świetny tancerz. Arens przyzna się nawet: „Gdybym się nie wstydził, sam chętnie bym z nim zatańczył” (D 53). Z kolei relacja z Michałem Podgórskim, który ostatecznie Markowi odbije Agnieszkę, będzie przypominała układ z Szymaniakiem, bo to dzięki Arensowi osiagnnie Podgórski tożsamościowa jednoznaczność („nauczyłem go patrzeć na świat oczami mężczyzny i zachowywać się jak mężczyzna”, D 123). Wcześniej Podgórski był „łamaga”, które to określenie u Dygata występuje - z pewnymi wyjątkami, pomieszczonymi właśnie w Disneylandzie - jako synonim nie-męskości. Arens uwielbianego Hemingwaya podejrzewał o bycie „zakonspirowanym łamaga”, niemniej jednak pisarz ten miał rozumieć „sprawy mężczyzn” (D 135). Przy innej okazji bohater powie wszakże: „Tu chcę zaznaczyć, że kiedy kogoś nazywałem łamagą, nie zawsze to musiało być obraźliwe. Czasem należało to nawet traktować właśnie przeciwnie” (D 151). Tak miało się dziać w przypadku partnera matki Arensa, jednakże ta nieśmiała próba rehabilitacji pojęcia nie zostanie szerzej wyjaśniona. Bywa, że również siebie Arens określa tym mianem (D 195). W taki też sposób traktował go ojciec, którego $n b$. sam uważał za łamagę (D 9). Jeśli jeszcze do tego dodać wprost wyrażoną niechęć do zdobywania kobiet (D 118), to skala tożsamościowych komplikacji będzie w miarę pełna.

Najwięcej takiego rodzaju mimetycznych zapośredniczeń znajduje się chyba w Podróży. Młodego Henryka Szalaja zbliża do Jurka Malinowskiego platoniczna miłość do Mary Pickford ${ }^{38}$. Afekt do gwiazdy działa jak alibi i „ma jeszcze tę dobra i piękną stronę, że rywalizacja nie dzieli, ale łączy [...]" (P 41). Do opisu owego koleżeństwa Dygat uruchamia prawdziwy dyskurs miłosny. Chłopcy w drugim dniu przyjaźni „unikali siebie jak kochankowie, którzy unikają się po pierwszym pocałunku” (P 41). Mowa też będzie o „wspólnocie w miłości” (P 42). W życiu Henryka tak pozostanie już na zawsze. Stefan Małek odbije mu w tańcu Wandę, co wpędzi go w małą depresję, wszakże nazajutrz z wielką serdecznością będzie odnosił się do konkurenta (P 60). Pomiędzy Henrykiem a Jadzią będą dwaj koledzy, Julek i Genio: „Musieli pannie Jadzi bardzo się podobać, bo nawet jemu się podobali [...]” (P 73). Po swoim „pierwszym razie” z Olą bohater od razu myśli o jej mężu i ma prosta satysfakcję z przyprawienia mu rogów. Chodzi jednak nie tylko o to, bo ,jeżeli Henryk poczuł się mężczyzna, to w tej pierwszej chwili zawdzięczał to raczej doktorowi Kępskiemu niż Oli” (P 99). To poczucie męskości okazuje się niemal od razu tożsame $\mathrm{z}$ wyrażanymi wprost lekceważeniem i pogardą wobec kobiet, zwłaszcza wobec ich zmistyfikowanej urody (P 101). Zaczepiony tuż po inicjacji seksualnej przez atrakcyjną dziewczynę Szalaj spluwa z odrazą i myśli: „To dziwka bezczelna

38 Lektura felietonu Wspomnienia kinomana sugeruje podtekst autobiograficzny: „Szybko przerzuciłem moje sympatie na Mary Pickford i jej pensjonarskie przygody i nie zamierzam ukrywać, że była moją drugą w życiu miłością" (U-1 47). 
[...], co ona sobie niby wyobraża? Co? Jej się zdaje, że ja nie wiem?” (P 102). Trudno jednak powiedzieć, co wie Szalaj. Tak samo niełatwo w pierwszej chwili wyjaśnić swoistą anorektyczność bohatera, która dopada go po zbliżeniach erotycznych. Patrząc na jedzącą Olę, czuje obrzydzenie, a spożywany przez nią „krem skojarzył mu się $z$ jakimiś okropnymi rzeczami [...]" (P 103). Podobnie zdegustowany będzie wobec Zity jedzącej mięczaki i wówczas nagle ujrzy w niej niewidoczną dotąd pospolitość i „rozmlaskanie” (P 230), przy następnej okazji spożywania posiłku przywodzi mu ona na myśl fokę z ogrodu zoologicznego albo dziecko przy piersi (P 237) ${ }^{39}$. Mimo odrazy, jaką momentami odczuwa do Zity („Wstrętna dziwka”, P 243), będzie przeżywał mściwą satysfakcję na myśl, że mógłby dzielić się kobietą z bratem Jankiem, będącym światowej sławy reżyserem. Ostatecznie do zbliżenia z prostytutką Zitą nie dojdzie, ale i tak pozwala mu to przezwyciężyć gnębiące go poczucie zazdrości, zawiści i poniżenia. Zgodnie ze swoim resentymentowym credo - „Dlatego dziś lepiej być mniejszym niż większym” (P 212) - wyniesie własne ubóstwo i marny los urzędniczy nad wszystkie przewagi materialne i symboliczne brata (P 204).

W sposób tyleż osobliwy, co jednoznaczny o związkach tego, co homospołeczne i mizoginizmu mówi krótkie opowiadanie $W$ kinie z tomu Pola Elizejskie. Już sama wizyta w kinie stanowi dla głównego bohatera, sierżanta polskiej armii, rodzaj ucieczki przed dziewczyną. Oboje byli mocno sobą znudzeni, lecz wydaje się, że nie można tego wytłumaczyć wyłącznie bariera językowa. Opóźniajacy się seans sprawił, iż sierżantowi robiło się „coraz markotniej i smutniej”. Co jednak najgorsze, ale i najciekawsze: „ckniło [mu] się trochę [...]” (N 72), lecz ta tęsknota nie zostaje wyjaśniona. Nie wiadomo, jak zakończyłaby się fatalna randka, gdyby bohater niejako w ostatniej chwili nie wypatrzył swojego kolegi z dzielnicy. Głośna rozmowa wzbudziła irytację widowni eleganckiego kina „Odeon”, awantura wisiała w powietrzu, bo okazało się, że wśród oglądających więcej było polskich żołnierzy i należeli oni do najagresywniejszych. Nastapiła jednak gorączkowa integracja, w wyniku czego już po chwili „trzech polskich żołnierzy szło ulicą trzymając się pod ręce i wesoło śpiewając, a w kinie obok wolnych krzeseł siedziały trzy ogromnie zdziwione angielskie dziewczyny”. „Angielskie dziewczyny”, czyli „małpy”, co nie potrafiły "gęby otworzyć, bo ludzkim językiem nie mówiły" (N 74).

Dziwne sa te idiosynkrazje bohaterów Dygata ujawniające się w ich relacjach z kobietami. Wydaje się, że mogłaby pomóc w ich objaśnianiu metaforyka, której używa Henryk Szalaj do opisania różnic między nim a bratem. Przedstawiając swoją relację z Jankiem, wyjawi on, że tym, co przesądziło o jego kiepskiej egzystencji, było to, co „geniuszowi zbędne, co we wrażliwości jest nadmierne, co w głębi przeżyć jest zawadzające [...], co mąciłoby konieczną geniuszowi rzeczowość kształtów i treści [...]” (P 116). I jeśli Janek pozostał „Z dynamiczną, esencjonalną i podstawowa, kosmiczna, biologiczna, matematycznie odmierzoną we własnych proporcjach inteligencją, wrażliwością i głębią [...]”, to Henryk został „obdarzony wyłącznie skrawkami ich zbędnej nadwyżki, tworami galaretowatymi i amorficznymi, nieprzydatnymi praktycznie do niczego, a o wszystkich pozorach organizacji konkretnych, uformowanych i aktywnych” (P 116). Skoro więc za własne niepowo-

39 W Jeziorze Bodeńskim bohater dzieli z Thomsonem odrazę do „haremu francuskich guwernantek” (J 17). Powie o nich: „Guwernantki [...] straszliwie cuchną” (J 18). 
dzenia oskarża on to, co w nim nadmierne, zawadzające, bezkształtne, galaretowate i amorficzne, to nietrudno skojarzyć owe właściwości z tym, co wzbudzało w nim największe obrzydzenie w widoku jedzacych kobiet. Były to krem i mięczaki, a zatem potrawy o podobnej, niestałej i lepkiej konsystencji. Łatwo więc stwierdzić, że w taki sposób uruchamiają się w Szalaju abiektalne lęki, związane z tym, co podług reguł edypalnego rozwoju musi zostać wyparte $z$ obszaru tożsamości ${ }^{40}$. Ten ciag synonimów abiektalności można wydłużać w nieskończoność: cielesność, fizjologiczność, nieczystość, kobiecość, niemęskość - słowem: łamagowatość. A także poczucie bierności i impotencji, których najbardziej dojmująco doświadczał bohater Jeziora Bodeńskiego i które opisywał w nieprzypadkowej retoryce:

...Czyn. Ach, czyn. Niemożność czynu, jakiegokolwiek czynu, to jest chyba najgorsze w tym wszystkim. Czasem zdaje mi się, że jestem watą. Wata jest miękka, leniwie rozlazła i też niezdolna do czynu. Ją moczy się lub czymś nasyca, przykłada do czegoś lub coś nią pociera, ale w tym wszystkim wata bierze tylko bierny udział. Żeby tak można spełnić jakiś czyn. Zdobyć się na tę śmiałość i determinację ducha, która jest nasieniem czynu. [J 121]

Nic dziwnego, że na myśl o własnych niemożnościach („Nie móc - to piekło”, J 229) bohater czuje się zhańbiony i zawstydzony, zastanawia się nawet nad samobójstwem. Tu reaktywny, resentymentowy nihilizm dławiący Dygatowych protagonistów sięga swojego kresu.

Skala tych doświadczeń nie musi być zaskoczeniem, jeśli zważyć, że nie chodzi tu wyłącznie o jakieś przygodne życiowe zaniechanie czy niedyspozycję. Chodzi tu o coś bardziej fundamentalnego i związanego z poczuciem męskiej tożsamości. Niemożność to groza nietożsamości i niemęskości. Kalle Berggren, podobnie jak Deborah Sarah David i Robert Brannon, na których się powołuje, pisze, że tradycyjna rola męska opierała się na czterech bardzo prostych prerogatywach:

no sissy staff, be a big wheel, be a sturdy oak, give'em hell" (nie bądź miękki, bądź ważniakiem, bądź twardy, niech inni się odpieprza). Innymi słowy, męskość polegała na dystansowaniu się od kobiecości i od bycia emocjonalnym, staraniu się o odniesienie sukcesu na drodze rywalizacji, kontroli sytuacji i wreszcie na agresywnym zachowaniu ${ }^{41}$.

Męskość to nie uwarunkowana anatomią tożsamość, lecz projekt będący reakcją upokorzonego narcystycznego ,ja” na doświadczenie bezsilności, przejściowości i zależności, co wyraża się właśnie przez wypieranie kobiecości i macierzyńskości. Oznacza to przesunięcie akcentów w stosunku do schematu edypalnego, w którym owo wyparcie jest czynnikiem tożsamościotwórczym. Taką funkcję zachowuje. U podstaw leży jednak nie wybór, ale reaktywne i resentymentowe odreagowanie. Męskość stanowi więc narcystyczną negację odniesienia, wyparcie uwarunkowania, „nie chce być wiązana z zależnością, pragnie poczucia niezależności i wolności od

Zob. J. Kr i s te va, Potęga obrzydzenia. Esej o wstręcie. Przeł. M. F a ls k i. Kraków 2007. Według P. B o u r di e u (Męska dominacja. Przeł. L. Ko p c i ew i c z. Warszawa 2004, s. 42) kobiety „z powodów "mitycznych" sytuują się „po stronie wewnętrznego, mokrego, niskiego, nieprawego".

41 K. B ergg r e n, Lepka męskość: poststrukturalizm, fenomenologia i podmiotowość $w$ krytycznych studiach nad męskościa. Przeł. W. Ś mi e ja. „Teksty Drugie” 2015, nr 2, s. 358. Mowa tu o książce The Forty-nine Percent Majority: The Male Sex Role (Ed. D. S. D a vi d, R. B r a n n o n. Reading, Mass., 1976). 
tej "pomieszczającej" [tj. matczynej, kobiecej - M. B.] siły, chce być samowystarczalna, odpowiednia sama sobie”. Do tego często dochodzi w sytuacji terapeutycznej i wówczas „pomieszczanie” analityka doświadczane jest przez analizanta jako „coś lepkiego, kleistego, przerażającego”42. Męskość stanowi tu „nieziszczalne marzenie o uniknięciu ran, zaprzeczeniu przemijania i zrzuceniu zależności - marzenie tak zniewalające, że bezustannie zagraża ono męskiej tożsamości”" ${ }^{43}$. Dlatego pozostaje ona w permanentnym kryzysie. Trwają w nim bez wątpienia bohaterowie Dygata, którzy nie tylko dojmująco odczuwają te powikłania, ale i sa ich niemalże zupełnie świadomi. Za wszelką cenę usiłują przestać być „maminsynkami” i usiłowanie to stanowi właśnie wyparcie tęsknoty do matki. Jeśli jednak ow narcyzm męski oznacza wyparcie intersubiektywności, to dla Dygata wiąże się to z zerwaniem z Gombrowiczem - zarówno z jego interakcyjną filozofią, jak i jej radykalnymi konsekwencjami w refleksji nad płcią ${ }^{44}$.

Można wszakże znaleźć u Dygata rzeczy komplikujące ów jednolity obraz. Ta osobliwa indolencja męska zostaje w pewnej mierze przepracowana w dyptyku, w jaki układa się, przynajmniej przed moimi oczami, mocno autobiograficzny i autotematyczny Pacific Panam Palisades oraz Jestem, jaka jestem z kobieta jako protagonistka. Bohater pierwszego utworu to pisarz, autor Jeziora Bodeńskiego, który samolotem leci do Ameryki, siedząc obok pianisty Bernarda Porcelina. To sprawia, że bohater jest zawieszony między zazdrością i zawiścią wywołanymi przez międzynarodową sławę jego przygodnego towarzysza podróży a satysfakcja z powodu poufałego $z$ nim obcowania. On sam usiłował trawiące go poczucie „niższości i podrzędności” przezwyciężyć napisaniem magisterium, oponował też przeciwko imputowaniu mu „wrodzonego, banalnego kompleksu niższości” (U-2 283). Skłonny jest raczej w sposób typowy dla Dygatowych protagonistów przepracować ów kompleks albo przynajmniej przedstawić go jako doświadczenie złożone i wyjątkowe. Tłumaczy to presja toksycznej rodziny („rodzina uważała mnie za kretyna, z którego nic nie wyrośnie”, U-2 283), uznawaną za częściowo uzasadnioną:

G. Ka rls s o n, Męskośćjako projekt: kilka uwag psychoanalitycznych. Przeł. F. Ma z u rki e wi c z. „Teksty Drugie” 2015, nr 2, s. 399.

Ibidem, s. 397.

44 K. Theweleit (Męskie fantazje. Przeł. M. Falkowski, M. Herer. Przekł. przejrzał A. Ży chlińs ki. Warszawa 2015, s. 66-68, 304-306, 391-433), opisujący procesy kształtowania męskości nowoczesnej i faszystowskiej, rozpoznaje szereg mechanizmów obronnych związanych z zagrażająca kobiecością: od różnych form dystansowania się wobec kobiet i kobiecości (np. pomijanie w biograficznych narracjach), fantazmatów kobiecości wzniosłej i odseksualizowanej oraz upadłej i cielesnej, konstruowania męskiego ,ja” za pomoca oddzielenia i redukcji przy użyciu opozycji męskie-kobiece, zewnętrzne-wewnętrzne, publiczne-prywatne, oraz metaforyki substancji i stanów nieczystych o niestałej, lepkiej konsystencji, poprzez mizoginizm, seksizm i otwarta przemoc, po różne przejawy sublimacji czy silnych zależności homospołecznych (męskie wspólnoty, męskie przyjaźnie, relacje w trójkącie, przynależność do organizacji, fascynacje militarne, zaangażowania polityczne i patriotyczne). Powstrzymuje się jednak przed uznaniem tych ostatnich tendencji za latentnie homoseksualne. G. L. M o s s e w książce na temat nowoczesnej męskości (The Image of Man. The Creation of Modern Masculinity. New York 1998, s. 5, 12, 74-76) również twierdzi, że kluczowe znaczenie miała dla niej opozycja „zewnętrznego wyglądu i wewnętrznej cnoty” (ibidem, s. 5) oraz kobiecości jako negatywnego kontekstu potrzebnego do samookreślenia się i jednocześnie hipostazy najbardziej traumatycznych zagrożeń i lęków. 
Nawet zupełnie nieźle się z tym czułem, ale w żadnym wypadku nie da się tego podciagnąć pod Freudowskie, naukowo ujęte kompleksy, których przyczyny trzeba wyciągać, babrając się w czyichś lepkich jak błoto na wsi w dzień Wielkanocy pomrokach duszy. Ze mną sprawa była zupełnie jasna. [U-2 283]

Dygat w ostatnich tekstach całkiem często wspomina psychoanalizę freudowska, lecz trudno doprawdy wierzyć tym sugestiom, bo mimo lakoniczności więcej w nich uprzedzeń niż trafnych intuicji. Jak to jednak bywa - przynajmniej zdaniem Slavoja Žižka, ale wbrew przekonaniom Dygata - nieświadomość nie jest niczym do odkrycia, bo lokuje się na jawnej powierzchni i w tym sensie protagonista Pacific Panam Palisades ma rację, twierdząc, iż z nim „sprawa była zupełnie jasna”. Dobrze znana metaforyka sugeruje, że znowu mowa o najważniejszych obsesjach właściwych ujętemu zbiorczo bohaterowi prozy Dygata. Nieoczekiwany sukces debiutanckiej książki protagonisty analizowanego opowiadania sprawia, iż zaczął on wierzyć, że jest „czymś więcej niż nieudanym maminsynkiem [...]” (U-2 284). Nic $\mathrm{z}$ tego, jak stwierdza:

Zrozumiałem, jak Edyp, w spóźnionym momencie olśnienia, że daremny to trud starać się umknąć przed uściskiem Losu i Przeznaczenia. Stało się: byłem Kretynem, z którego nic nie wyrosło w życiu. [U-2 285]

Potem, pod wpływem nowych upokorzeń, zachodzi w nim kolejna konwersja i teraz już wie, iż niepotrzebnie przyjął nakaz, „by ukorzyć się, poczuć się małym i niedołężnym” (U-2 285). Tymczasem należało zachowywać się zupełnie inaczej: „Bykiem! Już wiem, że trzeba zawsze i wszędzie atakować bykiem" (U-2 286). Przychodzi na myśl Trans-Atlantyk, gdzie Gonzalo był „nie Bykiem [...], a tylko krową, sama zaś „krowa” obok „kobyły” stanowi tam figurę grozy niemęskości ${ }^{45}$. Nawet jeśli ta aluzja jest mimowolna, to ostateczny wniosek utrzymany zostanie w duchu tej powieści: „Uważam za nie zasłużoną łaskę, że jestem, kim jestem, i nic mnie nie łączy ze Stadem, ustawicznie i z ponurym pomrukiem atakującym się bykiem” (U-2 286).

Opowiadanie Jestem, jaka jestem dałoby się czytać jako swoistą palinodię maskulinistycznych i mizoginicznych wątków $z$ innych powieści. Główną bohaterkę, Annę Tarczyńską (zwaną częściej Hanna), która może się wydawać wprawdzie naiwna i prostoduszna, konsekwentnie określa się też jako pensjonarkę (U-2 46), aczkolwiek z gorliwością faktycznie iście Młodziakowską zapewnia ona, iż jest uświadomioną erotycznie „nowoczesną dziewczyna” (U-2 44). Jeśli uwzględnić to, że jej pierwowzorem miała być Kalina Jędrusik, to jeszcze więcej przemawia za tym, żeby patrzeć na tę bohaterkę bardziej serio. Najciekawsze jest na pewno to, iż przedstawiono ja jako ofiare patriarchalnego świata i seksistowskiego traktowania przez mężczyzn. Wprawdzie aspekt teatralności wciąż jest wyraźny i nader często pojawiają się pochodne kategorie (aktorstwa 〈U-2 45-46〉, ról i gier międzyludzkich

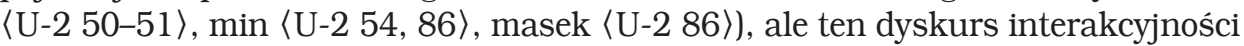
podlega zakwestionowaniu przez sugestię, że maska zostaje uznana za coś nieodzownego i koniecznego:

Dlatego myślę sobie: może lepiej nie usiłować im tych masek zdzierać z twarzy?

W. Go mbrowicz, Trans-Atlantyk. Red. nauk. J. Błońs ki. Kraków 1986, s. 41, 70. 
Czy w ogóle można żyć, jeżeli nie przyzna się pozorom rządzących praw? A co będzie, jeżeli oni sami, nie proszeni, maski sobie $z$ twarzy zedrą i strasznie mi się wykrzywią? Sprawy więc do tego w świecie doszły, iż naturalnym dążeniem powinno być nie zdzieranie masek z ludzkich twarzy, ale staranie się za wszelką cenę, by z tych twarzy nie opadały. [U-2 86]

Rezolutna Hania ma wprawdzie trochę wspólnego z resentymentowymi męskimi bohaterami Dygata („Rano, kiedy się budzę, przypominają mi się wszystkie krzywdy. I w ogóle ten bałagan, w którym żyję. Ogarnia mnie złość i chęć, żeby coś zrobić. Przeobrażać ludzi, upokorzyć ich”, U-2 7), w końcu jednak wypracuje sobie afirmatywny, omalże nietzscheański stosunek do świata i samej siebie („Głupio tak to powiedzieć, ale ja kocham życie. Kocham w nim właściwie wszystko, nawet to, że jestem nieszczęśliwa. [...] wszystko, co jest życiem, jest cudowne, jedyne i niepowtarzalne”, U-2 39-40). Refleksja bohaterki okazuje się wieloznaczna, lecz można z niej wyczytać nieco antypatriarchalnego optymizmu: ,jestem, jaka jestem, bez względu na płeć i wszelkie wypływające $z$ tego konsekwencje" (U-2 102; zob. też U-2 38, 48, 54). Co ciekawe: tak samo o sobie mówił bohater Jeziora Bodeńskiego: „Jestem, jaki jestem, i nie mam zamiaru się zmienić” (J 128). On jednak tylko marzył o „innej męskości”, Hania konkretniej ją sobie wyobraża (U-2 56). Jak mi się wydaje, tylko tyle i aż tyle mówią utwory Dygata o „innej męskości”.

Wśród licznych „uczniów” Gombrowicza tym on się wyróżnia, iż na własną rękę dokonuje transpozycji niektórych intuicji „Mistrza” do pobocznych kontekstów. Oto Dygat, zachwycony Ferdydurka, nie tylko inspiruje się nią na wiele sposobów w Jeziorze Bodeńskim, ale zdaje się wyciągać daleko idące konsekwencje z jej antropologiczno-filozoficznego przesłania i tym samym antycypuje tematykę podjęta przez Gombrowicza w jego następnej powieści, Trans-Atlantyku. Tak jest, w Ferdydurce problematyka tożsamości narodowej nie należy do wątków najistotniejszych (co innego wycofany paratekst z Piekosińskim i Pietrasińskim!), a zatem dokonana przez Dygata transpozycja zagadnień interakcyjności do tego kontekstu stanowi oryginalne osiagnięcie. Co jeszcze ciekawsze i warte odnotowania, w przedmowie do drugiego wydania Dygat sugeruje, że „ogólny zamysł utworu” zrodził się w latach 1937-1939 (J 8), a to najprawdopodobniej czas przyjaźni z Gombrowiczem. Czyż powikłana ta sytuacja, mocno komplikujacca standardowe kategorie historycznoliterackiego opisu, nie jest świetnym przykładem omówionej przez Blooma sytuacji apophrades, w której pisarski adept kreuje swojego mistrza? ${ }^{46}$ Nie zgadzam się natomiast $z$ głosami sugerującymi, że ujęcie Dygata nie ustępuje ujęciu Gombrowicza - przynajmniej w kwestii radykalizmu ${ }^{47}$. Wolno w to wątpić, ponieważ w poglądach protagonisty sporo jest nieoczywistości czy ambiwalencji. To samo można powiedzieć o jego najbardziej radykalnych gestach.

Punkt wyjścia wydaje się obiecujący i jakby zgodny z wytycznymi gombrowiczowskimi. Bohater nie akceptuje posługiwania się dyskursem tożsamości narodowej, ponieważ skazuje go to na funkcjonowanie w porządku ogólności oraz pozbawia idiomatyczności:

Rozróżniają mnie jeszcze ludzie po tym, że jestem Polakiem. Ale i tu popadam w więź ich uogólnień. Nie jestem tym albo innym Polakiem, tylko właśnie Polakiem. [...] Ograniczaja mnie polskością jako

47 To sugeruje J a r zę b s ki w Pożegnaniu z emigracją (s. 133-134). 
jakimś pojęciem ustalonym i raz na zawsze zdecydowanym, pojęciem, które, mniej lub więcej słusznie, wyrobili sobie. [J 80]

Identyfikuje on ponadto cały szereg ideologii, począwszy od samego militaryzmu po konkretne mity narodowe: Francji („,To Francja trójkolorowego sztandaru i Marsylianki, o zaciętej, osmalonej dymami wojny twarzy [...]”, J 35), Niemiec („Niemcy maja kaisera, pikelhauby, krok pruski, podgolone łby i butę", J 36), Anglii i Ameryki (,gwiaździsty sztandar [...], wysocy anglosascy chłopcy [...]”, J 36-37). Jak to jednak u Dygata bywa, ów sceptycyzm wynika z rozczarowania, bo bohater powieści czuje się oszukany przez aliantów (J 39). Oskarża zachodnich sojuszników o polityczny koniunkturalizm, asekuranctwo, a przede wszystkim o niezrozumienie szczególnego polskiego losu. Te argumenty rozwinie i zradykalizuje w odczycie, który, jakkolwiek pozostaje kulminacyjnym momentem powieściowych zdarzeń, może stwarzać pozory nie tak bardzo wywrotowego, jak na ogół się sądzi ${ }^{48}$. Odczyt ma być prowokacją i buntem, ale zdaje się jedynie potwierdzać to, co powinien zakwestionować. Kończy się ponadto kolejną rejteradą bohatera, bo actes gratuits zaaranżowane wespół $\mathrm{z}$ Roullotem $\mathrm{w}$ trakcie odczytu mają wymiar defensywny i eskapistyczny. Sam wykład przynosi wizję pomieszaną i niejednoznaczną. Bohater przy użyciu anachronizującej stylizacji maluje obraz kraju biedy, partactwa, bylejakości, nieprofesjonalizmu, zacofania i ciemnoty. Trudno jednak nie odnieść wrażenia, iż mitologizuje tę rzeczywistość jako swojską i naszą, i nic dziwnego, że na koniec obraz ten nabiera sielankowych i sentymentalnych rysów. Idea mesjanistyczna również po raz kolejny broniona jest argumentem wyjątkowości polskiego doświadczenia, które pozostaje czymś całkowicie niezrozumiałym dla zachodnioeuropejskiego kręgu kulturowego (J 278) ${ }^{49}$. Na tle moralnego upadku Europy Polska okazuje się depozytariuszem prawdy, niezachwianych kryteriów pozwalających na sprawiedliwe wartościowanie i zupełnie wyjątkowym przykładem suwerenności i niezależności:

Tak, panowie, [...] zważcie, to jednak, że istnieje naród, dla którego białe jest białe, a czarne jest czarne, i nikt nie może go przekonać, że może to być inaczej. I naród ten nie umie być polityczny, bo musiałby na białe zacząc krzyczeć „czarne”, a na czarne „białe”, a on nie może, nie może, nie może, w żaden sposób nie może. A widząc, co wy tam na swoich fotelach wyrabiacie, nic innego nie może zrobić, jak westchnać i dać się ukrzyżować. Dla wyrównania. To za wasze grzechy ten naród wisi na krzyżu, oplwany, biczowany, cierpiący. [J 280]

W sposób typowy dla protagonistów Dygata bohater Jeziora Bodeńskiego miota się między niezależnością i nonkonformizmem a identyfikacją i poczuciem przynależności do wspólnoty. Kompleks niższości nie daje się u niego oddzielić od poczucia wyższości. Gorzka świadomość tragizmu polskiej historii co chwilę przeobraża się w fascynację wyjątkowością polskiego doświadczenia. Bohater Jeziora

G u t k o w s k a (op. cit., s. 24-27) w związku z odczytem skłonna jest mówić o „parodii pozytywnej”, ponieważ ironia Dygata dotykać by miała jedynie stereotypu literatury romantycznej, a nie jej samej. W takim sensie wpisuje się on w dyskusję na ten temat, a nawet proponuje obronę aktualności i czystości owego dziedzictwa.

49 Ten argument mocno wybrzmiewa w Karnawale (KD 28). Koszulka z Bogurodzicą z Dworca w Monachium jawiła się pewnie jako dowcipna i absurdalna fantazja, ale intuicja Dygata nie zawiodła, dziś koszulki z „Polską Walczącą” i „Żołnierzami Wyklętymi” noszą kibice i gimnazjaliści. 
Bodeńskiego, kontestując tradycję romantyczną, jest nie tylko w ogromnej mierze od niej uzależniony, ale prawdziwie nią oczarowany ${ }^{50}$. Powody bywają różne, czasem sytuacyjno-pragmatyczne i niemal cyniczne, gdyż do uwiedzenia Suzanne przyda się np. poezja romantyczna i historia Polski (J 59-61). Ponadto sprawia on wrażenie kogoś prawie organicznie wyczulonego na dyskurs antypolski. Sprowokowany złośliwościami na temat alkoholizmu Polaków, odpowiada w sposób wewnętrznie sprzeczny, bo odwraca argument, kierując go w stronę Francuzów i Anglików i wykorzystując nawet przesłanki historycznoliterackie, zaraz jednak dodaje, iż Polacy mają swoje szczególne powody, żeby pić (J 102). Co więcej, za chwilę chełpliwie dorzuci, że głowy Polaków są mocniejsze od głów Francuzów (J 103). Całkiem serio broni polskiej niezależności, bitności i przywiązania do wolności (J 107). Wreszcie sięga po stary mit polskiego winkelriedyzmu, wynosząc odwagę Polaków nad tchórzliwość Francuzów i Anglików (J 107). Przesłanie powieściowe jest zatem niejednoznaczne i raczej nie można powiedzieć, że bohater Jeziora Bodeńskiego to nie Dygat oraz że krytyki te zostają utrzymane na jakimś wyższym poziomie. Fakt, iż w każdej powieści pojawia się dziwnie duża liczba nie-Polaków mających dogłębną wiedzę na temat Polski albo przynajmniej szczególnie zainteresowanych sprawami polskimi - przy czym grupę tę stanowią najczęściej młode i urodziwe kobiety - sugeruje, że jest to obsesja samego autora.

Radykalizm powieściowego protagonisty osłabia nie tylko to, iż pozostaje on rezonerem zdolnym jedynie do patriotycznych deklamacji, bo praktyczna realizacja scenariuszy romantycznych nie najlepiej mu wychodzi. Jest bohater parodią kochanka i buntownika romantycznego. Kiepsko wypada w tej pierwszej roli, a ucieczka $z$ obozu (nie ma znaczenia, czy we śnie, czy na jawie) kończy się groteskowo, przynosząc gorzkie poczucie impotencji. W kontekście narodowym łączą się zatem - niczym w soczewce - wszystkie jego obsesje. Tak oto np. polemizuje on $z$ dziedzictwem mesjanizmu romantycznego:

Przeznaczeniem Polski jest zwycięstwo, ale losem - męczeństwo. Polska wie, niestety, jak kobieta dręcząca się w gorsecie, że jej z tym do twarzy. Aktorstwo Polski, grając rolę bohaterską, musi zakładać maskę męczeństwa i z niego czerpać tytuł chwały. Musi na moment zawisnąć na krzyżu, aby móc potem wybuchnąc świetlaną siłą zmartwychwstania. Zmartwychwstanie - oto chwalebny symbol Polski, który serdecznym potem wypracowali jej wieszczowie i poeci. Moc narodowa Polski zawiera się w zmartwychwstaniu. Polska od czasu do czasu musi zmartwychwstawać. A na to, żeby zmartwychwstawać, trzeba umierać w męczeństwie. [J 38]

Pojawiają się tu wszystkie fantazmaty bohaterów Dygata związane z zagadnieniami narodowości, męskości, kobiecości, czynu i aktorstwa. Ciekawe jest to połączenie kwestii tożsamości narodowej i płciowej. Wizja to trochę stereotypowa oraz seksistowska, bo krępujący gorset jest czymś nieodzownym, a Polska to kobieta i aktorka, ale główny bohater uważał także siebie za aktora. Najbardziej ciekawy okazuje się jednak fakt, że choć jest on członkiem wspólnoty piszących mężczyzn, związanych ze sobą krwią i atramentem (J 76), to jego relacja $z$ Polską zostaje zapośredniczona przez babkę. Takie słowa notuje protagonista w swoim pamiętniku:

50 Przyzna to protagonista Karnawału, stanowiącego swoisty, po trosze palinodyjny, ciag dalszy Jeziora Bodeńskiego (KD 16-17). 
Niemcy w Warszawie, Polska po krótkiej agonii zmarła. Czy zmarła? Chwilami wydaje mi się, że we mnie zaczyna się dopiero rodzić. Gdy umarła moja babka, dopiero wtedy zacząłem czuć w sobie jej życie. Przedtem były to nieokreślone chwile rzucane w ciagu dnia mocą przypadku, ścierające się z moimi chwilami czysto zewnętrznymi. Śmierć określiła je syntezą dążeń i celów. Chwile zmarłej babki trwają we mnie łańcuchem przyczyn i skutków. Moje chwile, którymi w ciągu dnia rozrządza przypadek, są dalszymi ogniwami tego łańcucha. Polska zmarła po krótkiej agonii. Czyż zmarła, skoro ja żyję? [J 77]

Wizje to znowu klasyczne, bo bohater wykorzystuje tradycyjne wyobrażenia oraz topikę Polski jako Kobiety i Matki, ewoluujące w ciagu dziejów od alegorii organicznych do alegorii cierpienia i śmierci - aczkolwiek dokonuje ich inwersji ${ }^{51}$. Takie osobliwe pomieszanie kwestii tożsamości płciowej i narodowej aż się prosi o psychoanalizę ${ }^{52}$. Nietrudno stwierdzić, że doświadczenia bohatera - trawiące go poczucie nostalgii i tęsknoty, połączone $\mathrm{z}$ dziwacznymi gestami i autokreacjami wyglądają tak, jakby nie mógł on wyjść poza żałobę i melancholię oraz towarzyszące im konsekwencje. Jak wiadomo, konkretnym powodem może być utrata ukochanej osoby, jej niecne zachowanie czy wiarołomność albo utrata abstrakcji w postaci „ojczyzny, wolności, ideału” ${ }^{3}$, ale zasadniczo zawsze w gre wchodzą jakieś nieprzepracowane konflikty z preedypalnej przeszłości, związane zwłaszcza z oralnymi i kanibalistycznymi popędami, a więc dotyczaccymi relacji z matką i uwewnętrznianiem ${ }^{54}$. Niewiedza odnośnie do tego, co zostało utracone, wynika stąd, iż pewna część doświadczen , ja” jest wyparta do nieświadomości i stamtąd determinuje relacje $z$ soba oraz innymi. Rezultat stanowi zablokowanie emocjonalno-libidinalne, gra „pozorów i masek” ${ }^{5}$, teatralne poniżanie samego siebie, opiewanie ideałów i norm, którym nie sposób sprostać.

Dygat jest blisko wszystkich tych skojarzeń. Bohaterowi Jeziora Bodeńskiego niewątpliwie mocno doskwiera podwójne sieroctwo, bo został on opuszczony przez Matkę i Ojczyznę ${ }^{56}$. Jednocześnie wręcz obsesyjnie usiłuje porzucić obie figury i ich uosobienie w postaci kobiecości, nieustannie odgrywając komedię miłosną i pozując na surowego moralistę. Wycofuje swoje libido z powrotem do ,ja”, by na koniec dokonać utożsamienia się z obiektem w sobie. Wskazuje na to ten dziwny, fanto-

Zob. M. J a n i o n, Niesamowita Stowiańszczyzna. Fantazmaty literatury. Kraków 2006, s. 257-299. Kapitalną analizę wyobrażeń Polski przeprowadził J. S ow a w książce Fantomowe ciało króla. Peryferyjne zmagania z nowoczesna forma (Kraków 2011, s. 351-430).

S. Fr e u d, Żałoba i melancholia. W: Psychologia nieświadomości. Przeł. R. Re szke. Warszawa 2009, s. 147.

Interpretacja feministyczna kładzie na to szczególny nacisk. Zob. U. C h ow a n i e c, Melancholia. Hasło w: Encyklopedia gender. Płeć w kulturze. Red. M. Rudaś-G rodzka [i in.]. Warszawa 2014, s. 300.

P. Dy b e 1, Melancholia-gra pozorów i masek. Koncepcja melancholii Sigmunda Freuda. W: Urwane ścieżki. Przybyszewski - Freud - Lacan. Kraków 2000, s. 150.

Skwarczyń ski (op. cit., s. 80) sugeruje, że w obliczu osobliwych i niejednoznacznych w swej wymowie zachowań bohatera Jeziora Bodeńskiego „zupełnym wyzwoleniem może być tylko powrót do łona matki". A co jeszcze ciekawsze, badacz łączy tę supozycję z jakimiś wstydliwymi tęsknotami człowieka i Polaka, pragnieniem śmierci oraz regresją Roullota do dzieciństwa, i wreszcie daje do zrozumienia, że wątki te składają się na całkiem możliwy wariant zakończenia utworu. $Z$ kolei J a n u s z k i e w i c z (Tropami egzystencjalizmu $w$ literaturze polskiej XX wieku, s. 122) rozwiązania dylematu Madonny-Ladacznicy upatrywał w najbardziej pożądanej przez bohaterów Dygata figurze matki - wedle wyjaśnień E. Fromma - dającej bezwarunkową akceptację i altruistyczne uczucie. 
matyczny, nekrofilski, pośmiertny los Polski, zawieszonej między życiem a śmiercią. Odwrotnie jednak niż w Trans-Atlantyku - Polska nie jest upiorem nawiedzającym jednostkę, upiorem „co od wieków zdycha, a zdechnąć nie może! [...] co wciąż się rodzi, a przecież wciąż Nieurodzony! [...] [co] wam ani Żyć, ani Zdechnać nie pozwalał, a na zawsze was między Bytem i Niebytem trzymał" 57 . Dygat daje alegorię czegoś bez początku i bez końca, dobrowolnej śmiertelności jako warunku możliwości odnowienia i trwania. Babka zmarła i w ten sposób zaczęła żyć w bohaterze. Podobnie Polska poczęła istnieć dla bohatera dopiero po śmierci w wyniku klęski wrześniowej. Dwie rzeczy warto zauważyć. Brzemienne ciało bohatera przestaje być ciałem męskim. Istnienie Polski jest w rezultacie osłabione, jako łańcuch przyczyn i skutków rządzonych prawem przygodności. Ambiwalencje towarzyszące rozterkom ideowym bohaterów Dygata, miotających się od odrzucenia do identyfikacji, negacji i interioryzacji, wydają się bliskie klasycznej formie przepracowywania żałoby jako uwewnętrznienia tego, co utracone i zarazem jego odzyskiwania przez fantazmatyczną substytucję. Oznacza to wszakże podwójną zdradę wobec tego, co utracone, ponieważ upamiętnienie opiera się na oswajającej idealizacji tego, co niemożliwe do przyjęcia. Ów niepewny ślad afirmacji życia i działania sygnalizuje jednak, że w jakiejś mierze przepracowaniu podlegają reaktywne niemożności trapiące bohaterów Stanisława Dygata.

\section{Abstract \\ MARIAN BIELECKI University of Wrocław}

REMOVING AND PUTTING A MASK ON STANISŁAW DYGAT AND WITOLD GOMBROWICZ

The article reflects Stanisław Dygat's artistic dependence on Witold Gombrowicz. Intertextual analysis of Dygat's output confirms what has casually been remarked by literary scholars as well as what he himself admitted to. The first phase of his writing is especially marked by strong influence of Gombrowicz's creativity and figure on Dygat. Grotesque poetics of a story, the protagonist's construction, parodical strategies are the effect of Dygat's inspiration by the novel Ferdydurke (30 Door Key). In his late creativity such borrowings are less numerous, but Dygat will always be interested in what in the context of Gombrowicz's writing is referred to as "interactivity" and "interpersonal." 